\title{
Does Institutional Quality and Economic Freedom Impact on Foreign Direct Investment? Evidence From Developing Countries
}

\author{
Shakib Hossain (Corresponding author) \\ Senior Lecturer, Department of Business Administration \\ East West University, Bangladesh \\ E-mail: shakibbhossain@gmail.com
}

Abu Zafar Ahmed Mukul

Assistant Professor, Department of Management and Finance

Sher-e-Bangla Agricultural University, Bangladesh

Received: November 5, 2018 Accepted: November 21, 2018 Published: November 26, 2018

doi:10.5296/ijafr.v8i4.13973

URL: https://doi.org/10.5296/ijafr.v8i4.13973

\begin{abstract}
Using panel data analysis, it is an attempt to estimates the significance of institutional quality and economic freedom on foreign direct investment for a sample of 79 developing countries from 1998 to 2014. Panel unit root, pedroni residual cointegration test, vector error correction model, generalized least square (GLS), feasible GLS (FGLS), pooled OLS, random effect, fixed effect, poisson regression, prais-winsten, generalized method of movement (GMM) and generalized estimating equation (GEE) method are utilizing for estimates the importance of institutional qualities and economic freedom for facilitating foreign direct investment. VECM confirms that there is a long run relationship among the tested variables means that commensurate institutional quality and substantive economic freedom stimulates foreign direct investment. According to the OLS method, for the institutional quality the coefficient implies that a one standard deviation improvement in political stability and absence of violence, government effectiveness, regulatory qualities, rules of law and control of corruption increases FDI by $24.6 \%, 31.6 \%, 12.8 \%, 23.9 \%$ and $37.7 \%$ and on the other hand for the economic freedom, the coefficient implies that a one standard deviation improvement
\end{abstract}


in business freedom, trade freedom, government size, investment freedom, property rights, freedom from corruption, labor freedom, financial freedom, fiscal freedom, monetary freedom increases FDI by 28.4\%, 32.7\%, 29.5\%,22.8\%, 29.0\%, 36.4\%,29.3\%, 37.5\%, 46.1\% and $38.2 \%$ respectively. By using the other methods like random effect, fixed effect, poisson regression, prais-winsten and generalized estimating equation (GEE) method explores that both the institutional quality and economic freedom are influencing on FDI in the developing countries.

Keywords: Institutional quality, Economic freedom, Foreign direct investment, Generalized least square, Poisson regression, Generalized estimating equation

\section{Introduction}

Capital flows, especially foreign direct investment (FDI) is one of the key components of globalization which brings integration of the different developed economic with the developing countries. International trade has doubled because of trade liberalization; flows of foreign direct investment have increased tremendously by a factor of 10 around the world. Overall, the developing world has seen its share of FDI in aggregate net resource flows increase from a paltry 5.3\% in 1980 to more than $60 \%$ in 2000 (Yeyati et al, 2007).

Especially economic competitiveness is accelerates and economic structures is transforming very rapidly because of FDI in many developing countries. Li and Liu (2005) examine a panel of 84 countries over the period 1970 - 1999 to understand whether FDI triggers economic growth. Their result reveals that FDI not only promotes growth directly, but also increases growth with its interaction term. They further test their hypothesis in two sub-sample; developed and developing countries by dividing the whole sample (84 countries). Again the result confirms that in both developed and developing countries, FDI promotes economic growth. They find that a 10 percent increase in FDI (as a percentage of GDP) leads to a 4.1 percentage-point increase in the rate of economic growth. Li and Liu elucidation may be not universe; different factors are associated for ensuring the economic advancement. Considering the importance of macroeconomic factors in attracting FDI inflows, recent expertise consider that institutional quality and economic freedom is ineluctable ingredients for ensuring uninterrupted flow of investment. Recent studies have highlighted the essential role played by institutional factors in creating a more attractive investment climate (Nasir and Hassan, 2011) and different studies reveals that economic freedom not just ensure the FDI but also ensure the economic growth in a developing country (Azman-Sainiet et al. (2010).

Now inevitable question have raised do institutional quality and economic freedom really facilitated FDI? It is completely argumentative and a debatable issue in today's phenomenon depends on the manifold factors like market size and economic stability. To explore this work the paper has used the Kaufmann et al. (2007) work that identified the six elements as a institutional quality that comprised with voice and accountability, political stability, government effectiveness, regulation, law, corruption and aggregate governance and considering the importance of economic freedom, Heritage Foundation developed the Economic Freedom Index (EFI) based on these policy parameters and that comprised with the business freedom, investment climate, trade openness, monetary and fiscal environment 


\section{Mll Macrothink}

International Journal of Accounting and Financial Reporting

ISSN 2162-3082

2018, Vol. 8, No. 4

in the index. Each and every factor separately and independently influences the foreign direct investment.

According to the Jude and Levieuge (2013) have used a sample of 94 developing countries over the period 1994-2009 and a panel smooth transition regression (PSTR) to identify the threshold of institutional quality that influence the FDI growth effect. They discover that the advancement of the institutional framework should precede FDI attraction policies to benefits from FDI-led growth and that. Zafar Mueen Nasir and Arshad Hassan (2011) conducted a research work among South Asian countries 1995-2008 by using panel data analysis and fixed effects model and explores that there is a significant positive relationship between economic freedom score and FDI inflows.

This view, however, is disputed by the different authors like Habib and Zurawicky (2002), Li and Filer (2004), Li (2005), Henisz (2000), Moskalev (2007) and Zhu (2007). Li (2005) have argued that poor institutional quality does not necessarily mean the lack of protection. In an environment of poor institutional arrangement, MNCs strategically adjust to the local business climate and pay bribes in order to obtain business contracts (Zhu, 2007). Poor institutional arrangement may also offer enhanced investment opportunities for MNCs. In an environment of poor institutional arrangement, rent-seeking activities are pursued not only by politicians and policy makers but also by large MNCs. Relation-based systems are often controlled by powerful rulers who tend to favor big business ( $\mathrm{Li}, 2005)$.

Yassaman Saadatmand and Jeremy Choquette (2012) accomplishing a research work among 51 African countries from 1998 to 2009 by applying panel data regression method and discover that economic freedom discourages FDI inflows to the selected African countries.

To explore the effects of institutional quality and economic freedom on FDI, the paper is incorporated with the, literature review, model specification, empirical evidence and conclusion.

\section{Literature Review}

Because of the radical transition of the business and its relevant functions, traditional determinants (wage costs, infrastructure or macroeconomic policy) of FDI is no longer hold rather less traditional determinants has become more important, like institutions or economic freedom.

Unremitting transmutation of the economy and business function, the common factors like Market size (Asiedu (2006); Mlambo (2006) and Zhang (2008), Human Capital (Noorbakhsh et al. (2001), Dutta and Osei-Yeboah (2010), Infrastructure (Kok and Ersoy (2009) ,Macroeconomic stability (Chakrabarti 2001; Onyeiwu and Shrestha 2004), Financial Development (Alfara et al., 2004 and Durham, 2004) facilitated Foreign Direct Investment(FDI) but not substantial and meaningful way.

According to Busse and Hefeker (2007) and Ali et al. (2010), interprets that institutions can increase and optimize not only the FDI quantity, but also their quality. Institutional quality along with the economic freedom is a significant determinant of foreign direct investment as 
well as a noteworthy factor in economic growth (e.g., Barro, 1997; Dawson, 1998; Estrin, Bevan and Meyer, 2001; Ghura and Goodwin, 2000; Heckelman, 2000).

Different studies have argued that there is a robust relationship between non-economic factors, such as institutional quality and FDI (Busse and Hefeker 2005; Daude and Stein 2007). According to these global studies, a government's political stability, regulatory quality, rule of law, and level of corruption have a statistically significant effect on foreign investment. On the other hand, Gwartney (2009) penetratingly determined that countries with having enormous amount of economic freedom leads higher shares of private investment in GDP, higher productivity of private investment, grow more rapidly and achieve higher levels of per capita income than countries with lower levels of economic freedom.

According to Daude and Stein (2007) demonstrates that inward FDI is deeply influenced by the quality of institutions. Through a contemplative and vigorous research work accomplish by Rodrik and Subramanian (2002) emphasized on the supremacy of institutions over other determinants of FDI which is supported by Wernick, Haar and Singh (2009) arguing that "good" political and governance institutions reduce economic and political uncertainties and promote efficiency as effective governing institutions provide the necessary legal framework for economic growth and socio-economic development. Concentrate on the Marta Bengoa, Blanca Sanchez-Robles (2003) empirical work among 18 different Latin-American countries base on panel data analysis from 1970 to 1999, find out that the host country's economic freedom is found to be a positive and statistically significant determinant of FDI inflows.

The relationship between investment climate and private investment decisions has shown that "better political and governance institutions improve the investment climate by enhancing bureaucratic performances and predictability" (Aysan and Veganzones-Varoudakis, 2007) which reduces companies' costs of performing their business activities and economic freedom has expand the confidence level of the entrepreneur who enormously concentrate on accomplishing his business function and help to expand the economic growth and per capital income (e.g., De Haan et al., 2006; Azman-Saini et al., 2010; Compton et al., 2011). Institutional quality assists to increase the entrepreneur capacity of the local producer. Huang (2003) notes that poor institutions reduce the supply of local entrepreneurship; high quality institutions increase local entrepreneurship.

Several studies such as Bénassy-Quéré et al. (2007) and Busse and Groizard (2008) have stressed the potential positive role of good institutional quality in economic development, in particular as an attraction to further persuade inflows of FDI. Bengoa, Marta, and Sanchez-Robles (2003) investigated the relationship between economic freedom and foreign direct investment by using panel data of 18 different Latin American countries from the period 1970 to 1999. Empirical results illustrated that economic freedom facilitated FDI inflow and the economic growth was also found definitely related with FDI.

Institutional quality and economic freedom may not always a considering factor for FDI especially in developing countries. Sometime weak institutional quality facilitates foreign direct investment. Hausmann and Fernández- Arias (2000) claim that developing countries with weak institutions can actually attract more FDI because investors sometimes prefer to 


\section{MlMacrothink}

International Journal of Accounting and Financial Reporting

ISSN 2162-3082

2018, Vol. 8, No. 4

operate directly in unregulated environments, as the cost of engaging in more developed markets can be high.

Absorbing capacity of the host country is inevitable factors rather than the economic freedom in many developing countries. Multinational firms not just seeking the exploring resources rather also consider the availability of the human capacity that encourages them to make rigorous investment.

Using data on 80 countries for the period 1979-98 Durham (2004), have failed to identify a positive relationship among FDI, economic freedom and economic growth, based on his empirical work he advocated that the effects of are contingent on the "absorptive capability" of host countries.

\section{Model Specification}

This paper is mainly explores the consequence of institutional quality and economic freedom on stimulating FDI by using panel data analysis for a sample of 79 different developing countries from 1998-2014. As part of the methodological design, the basic equation is illustrated below:

$$
\begin{aligned}
\text { FDI } & =\alpha_{0}+\alpha_{1} \text { PoliticalStability }+\alpha_{2} \text { Government effectiveness }+\alpha_{3} \text { Regulatory Quality } \\
& +\alpha_{4} \text { Rules of Law }+\alpha_{5} \text { Control of Corruption }+\alpha_{6} \text { Businesss Freedom } \\
& +\alpha_{7} \text { Trade Freedom }+\alpha_{8} \text { Government Size }+\alpha_{9} \text { Investment Freedom } \\
& +\alpha_{10} \text { Property Rights }+\alpha_{11} \text { Freedom from Corruption }+\alpha_{12} \text { Labor Freedom } \\
& +\alpha_{13} \text { Financiaal Freedom }+\alpha_{14} \text { Monetory Freedom }+\alpha_{15} \text { Democracy }+e_{t}
\end{aligned}
$$

Where $\alpha_{0}, \alpha_{1-} \alpha_{13}$ are parameters to be estimated.

$\mathrm{e}_{\mathrm{t}}$ is stochastic error terms assumed to be independently and identically distributed.

For measuring the significance of institutional quality and economic freedom on the incessant flow of foreign direct investment different methods have used. .

At first for indentifying whether data are stationary or not for measuring it panel unit root test is being accomplished.

\subsection{Panel Unit Root Test: Levin, Lin and Chu}

Levin, Lin and Chu start panel unit root test by consider the following basic ADF specification.

$$
D Y_{i t}=\alpha Y_{i t-1}+\sum_{j=1}^{\mathrm{Pi}} \beta_{\mathrm{it}} \mathrm{DY} Y_{\mathrm{it}-\mathrm{j}}+\mathrm{X}_{\mathrm{it}}^{*} \delta+\varepsilon_{\mathrm{it}}
$$

Where,

$D Y_{i t}=$ difference term of $Y_{i t}$

$\mathrm{Y}_{\mathrm{i} t 1}=$ panel data 
$\alpha=\rho-1$

$\mathrm{p}_{\mathrm{i}}=$ the number of lag order for difference terms

$\mathrm{X}_{\mathrm{it}}^{*}=$ exogenous variable in model such as country fixed effects and individual time trend

$\varepsilon_{\mathrm{it}}=$ the error term of equation 2

LLC panel unit root test has null hypothesis as panel data has unit root as well as can present below that:

$\mathrm{H}_{0}$ : null hypothesis as panel data has unit root (assumes common unit root process)

$\mathrm{H}_{1}$ : panel data has not unit root

\subsection{Im, Pesaran and Shin}

The properly standardized $\mathrm{t}^{*}$ NT has an asymptotic standard normal distribution and also it was rewritten to be new t-statistics as well as can show below that: (see equation 3).

$$
\mathrm{W}_{\mathrm{t}^{*} \mathrm{NT}}=V_{\mathrm{n}}\left[\left(\mathrm{t}_{\mathrm{NT}}-\mathrm{N}^{-1} \sum_{\mathrm{t}=1} \mathrm{E}\left(\mathrm{t}_{\mathrm{iT}}\left(\mathrm{p}_{\mathrm{i}}\right)\right)\right)\right] / \sqrt{ }\left(\mathrm{N}^{-1} \sum_{\mathrm{i}=1}^{\mathrm{n}} \operatorname{var}\left(\mathrm{t}_{\text {ix }}\left(\mathrm{p}_{\mathrm{i}}\right)\right)\right)
$$

Where, $\mathrm{W}_{\mathrm{t} * \mathrm{NT}}$ is $\mathrm{W}$-statistics has been used to test panel data based on Im, Pesaran and Shin techniques. Also this technique has non-stationary as null hypothesis as well as to show below that:

$\mathrm{H}_{0}$ : null hypothesis as panel data has unit root (assumes individual unit root process)

$\mathrm{H}_{1}$ : panel data has not unit root

\subsection{Fisher-Type Test Using ADF and PP-Test (Maddala and Wu and Choi)}

Madala and $\mathrm{Wu}$ proposed the use of the Fisher $(\mathrm{P} \lambda)$ test which is based on combining the P-values of the test-statistics for unit root in each cross-sectional unit. Let $p_{i}$ are $U[0,1]$ and independent, and $-2 \log _{\mathrm{e}} \mathrm{p}_{\mathrm{i}}$ has a $\chi^{2}$ distribution with $2 \mathrm{~N}$ degree of freedom and can be written in equation 4.

$$
\mathrm{P} \lambda=-2 \sum_{\mathrm{i}=1}^{\mathrm{N}} \log _{\mathrm{e}} \mathrm{p}_{\mathrm{i}}
$$

Where,

$\mathrm{P}_{\lambda}=$ Fisher $\left(\mathrm{P}_{\lambda}\right)$ panel unit root test

$\mathrm{N}=$ all $\mathrm{N}$ cross-section

$-2 \sum_{\mathrm{i}=1}^{\mathrm{N}} \log _{\mathrm{e}} \mathrm{p}_{\mathrm{i}}=$ it has a $\chi^{2}$ distribution with $2 \mathrm{~N}$ degree of freedom

In addition, Choi demonstrates that :( see more detail of Choi demonstrates that in equation 5).

$$
\mathrm{Z}=\left(1 / \sqrt{ } \mathrm{N}_{\mathrm{i}=1}\right)\left[\sum_{\mathrm{i}=1}^{\mathrm{N}} \Theta_{\mathrm{i}}{ }^{-1}\left(\mathrm{p}_{\mathrm{i}}\right)\right]-->\mathrm{N}(0,1)
$$

Where,

$\mathrm{Z}=\mathrm{Z}$-statistic panel data unit root test 
$\mathrm{N}=$ all $\mathrm{N}$ cross-section in panel data

$\Theta_{\mathrm{i}}^{-1}=$ the inverse of the standard normal cumulative distribution function

$\mathrm{p}_{\mathrm{i}}=$ it is the $\mathrm{P}$-value from the $\mathrm{i}^{\text {th }}$ test

Both Fisher (P) Chi-square panel unit root test and Choi Z-statistics panel data unit root test have non-stationary as null hypothesis as well as to show below that:

$\mathrm{H}_{0}$ : null hypothesis as panel data has unit root (assumes individual unit root process)

$\mathrm{H}_{1}$ : panel data has not unit root.

\subsection{Hadri}

The Hadri test for panel data has the hypothesis to be tested is $\mathrm{H}_{0}$ is null hypothesis and $\mathrm{H}_{1}$ is against null hypothesis and can show below that:

$\mathrm{H}_{0}$ : null hypothesis as panel data has not unit root (assumes common unit root process)

$\mathrm{H}_{1}$ : panel data has unit root

\subsection{Panel Cointegration Test}

In order to solve the spurious regression problem and violation of the assumptions of the classical regression model, cointegration analysis is used to examine the long run relationship between the variables. This test is mainly accomplished for identifying the long run relationship among institutional quality, economic freedom and FDI.

$$
Y_{i, t}=\alpha_{1}+\beta_{1 i x_{1 i, t}}+\beta_{2 i} x_{2 i, t}+\ldots+\beta_{M i} X_{M i, t}+e_{i, t}, \quad t=1, \ldots . T ; i=1, \ldots N
$$

Here, $\mathrm{Y}$ indicates the dependent variable like FDI and $\mathrm{X}_{1}$ to $\mathrm{X}_{\mathrm{m}}$ indicates the different independent variables. (See in details Table 2)

Another method have used that is known as a Kao for estimating the long run relationship between the variables. Kao have used both DF and ADF to test for co-integration in panel as well as this test similar to the standard approach adopted in the EG-step procedures. Also this test start with the panel regression model as set out in equation 7.

$$
Y_{i t}=X_{i t} \beta_{i t}+Z_{i t} \gamma_{0}+\varepsilon_{i t}
$$

Where $\mathrm{Y}$ and $\mathrm{X}$ are presumed to be non-stationary and :( see equation 8 )

$$
\mathrm{e}_{\mathrm{it}}=\rho \mathrm{e}_{\mathrm{it}}+\mathrm{V}_{\mathrm{it}}
$$

where $\hat{e}^{\wedge}=\left(Y_{i t}-X_{i t} \beta_{i t}-Z_{i t y} \hat{y}\right)$ are the residuals from estimating equation 8 . To test the null hypothesis of no co-integration amounts to test $\mathrm{H}_{0}: \rho=1$ in equation 8 against the alternative that $\mathrm{Y}$ and $\mathrm{X}$ are co-integrated (i, e., $\mathrm{H}_{1}: \rho<1$ ).

\subsection{Vector Error Correction Model}

The purpose of VECM model is to indicate the speed of adjustment from the short run equilibrium to the long run equilibrium state between the variables from welfare to country 


\section{Macrothink}

International Journal of Accounting and Financial Reporting

ISSN 2162-3082

2018, Vol. 8, No. 4

risk. The greater the coefficient of the parameter the higher the speed of adjustment of the model from short runs to long run. Considering the basic equation (1), the VECM model is specified as follows:

$$
\begin{aligned}
& \mathrm{K} \\
& \Delta \mathrm{DFDI}=\alpha_{0}+\alpha_{1} \sum \Delta \text { Political Stability } \mathrm{t}_{\mathrm{t}-1}+\alpha_{2} \sum \Delta \text { Government effectivesness }_{\mathrm{t}-1} \\
& \mathrm{t}=1 \quad \mathrm{t}=1 \\
& \mathrm{~K}
\end{aligned}
$$

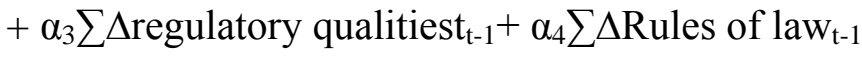

$$
\begin{aligned}
& \mathrm{t}=1 \quad \mathrm{t}=1 \\
& \mathrm{~K} \\
& +\alpha_{5} \sum \Delta \text { Control of corruption }_{\mathrm{t}-1}+\alpha_{6} \sum \Delta \text { Business freedom }_{\mathrm{t}-1} \\
& \mathrm{t}=1 \quad \mathrm{t}=1 \\
& \mathrm{~K} \\
& +\alpha_{7} \sum \Delta \text { Trade Freedom } \mathrm{t}_{-1}+\alpha_{8} \sum \Delta \text { Government Size }_{\mathrm{t}-1} \\
& \mathrm{t}=1 \quad \mathrm{t}=1 \\
& \mathrm{~K} \\
& +\alpha_{9} \sum \Delta \text { Investment Freedom }_{\mathrm{t}-1}+\alpha_{10} \sum \Delta \mathrm{D} \text { Property Rights } \mathrm{t}_{\mathrm{t}-1} \\
& \mathrm{t}=1 \\
& \mathrm{t}=1 \\
& +\alpha_{11} \sum \Delta \mathrm{D} \text { Freedom from coruption } \mathrm{t}_{\mathrm{t}-1}+\alpha_{12} \sum^{\mathrm{K}} \Delta \mathrm{D} \text { Labor Freedomt }-1 \\
& \mathrm{t}=1 \quad \mathrm{t}=1 \\
& +\alpha_{13} \sum^{\mathrm{K}} \Delta \text { Financial Freedom }_{\mathrm{t}-1}+\alpha_{14} \sum^{\mathrm{K}} \Delta \mathrm{D} \text { Monetary Freedom } \mathrm{t}_{\mathrm{t}-1} \\
& \mathrm{t}=1 \quad \mathrm{t}=1 \\
& \mathrm{~K} \\
& +\alpha_{15} \sum \Delta \mathrm{D} \text { Democracy }_{\mathrm{t}-1}+€_{\mathrm{I}} \\
& \mathrm{t}=1
\end{aligned}
$$

Where the $€_{\mathrm{I}}$ is the error term, ECM (-1) is the error correction term, $\beta$ i captures the long run impact. The short run effects are captured through the individual coefficients of the differenced terms $(\alpha)$ while the coefficient of the ECM variable contains information about whether the past values of variables affect the current values. The size and statistical significance of the coefficient of the ECM measures the tendency of each variable to return to the equilibrium. A significant coefficient implies that past equilibrium errors play a role in determining the current outcomes.

Considering the demand of the paper when $\Omega$ is known, $\beta$ is efficiently estimated with generalized least squares (GLS).

$$
\widehat{\beta}_{\mathrm{GLS}}=\left(\mathrm{X}^{\prime} \widehat{\Omega}^{-1} \mathrm{X}\right)^{-1} \mathrm{X}^{\prime} \widehat{\Omega}^{-1} \mathrm{y}
$$

Instead of assuming the structure of heteroskedasticity, the work may estimate the structure of heteroskedasticity from OLS. First, estimate $\widehat{\Omega}$ from OLS and, second, use $\widehat{\Omega}$ instead of $\Omega$.

$$
\hat{\beta}_{\mathrm{FGLS}}=\left(\mathrm{X}^{\prime} \widehat{\Omega}^{-1} \mathrm{X}\right)^{-1} \mathrm{X}^{\prime} \widehat{\Omega}^{-1} \mathrm{y}
$$




\section{1l Macrothink}

International Journal of Accounting and Financial Reporting

ISSN 2162-3082

2018, Vol. 8, No. 4

After GLS and FGLS the paper has also tested OLS. A standard panel OLS estimator for the coefficient $\beta_{i}$ given by:

$$
\beta_{i, O L S}^{\wedge}=\left[\sum_{i=1}^{N} \sum_{t=1}^{T}\left(X_{i t}-X_{i}^{*}\right)^{2}\right]^{-1} \sum_{i=1}^{N} \sum_{t=1}^{T}\left(X_{i t}-X_{i}^{*}\right)\left(Y_{i t}-Y_{i}^{*}\right)
$$

Where

$\mathrm{i}=$ cross-section data and $\mathrm{N}$ is the number of cross-section

$\mathrm{t}=$ time series data and $\mathrm{T}$ is the number of time series data

$\hat{\beta}_{\mathrm{i} \text { OLS }}=\mathrm{a}$ standard panel OLS estimator

$\mathrm{X}_{\mathrm{i}}=$ exogenous variable in model

$\mathrm{X}_{\mathrm{i}}^{*}=$ average of $\mathrm{X}_{\mathrm{i}}^{*}$

$\mathrm{Y}_{\mathrm{it}}=$ endogenous variable in model

$\mathrm{Y}^{*}{ }_{\mathrm{i}}=$ average of $\mathrm{Y}^{*}{ }_{\mathrm{i}}$

The most commonly used models in panel data analysis are fixed effects (FE) and random effects (RE) regressors in linear regression using ordinary least squares (OLS).

Here in this paper the fixed effects model is used binary variables. So the equation for the fixed effects model becomes:

$$
\mathrm{Y}_{\mathrm{it}}=\beta_{0}+\beta_{1} \mathrm{X}_{1}, \text { it }+\ldots+\beta_{\mathrm{k}} \mathrm{X}_{\mathrm{k}} \text {, it }+\gamma_{2} \mathrm{E}_{2}+\ldots+\gamma_{\mathrm{n}} \mathrm{E}_{\mathrm{n}}+\mathrm{u}_{\mathrm{it}}
$$

Where,

$\mathrm{Y}_{\mathrm{it}}=$ is the dependent variable (DV) is FDI where $\mathrm{i}=$ entity and $\mathrm{t}=$ time.

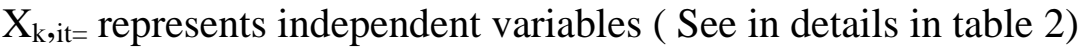

$\beta_{\mathrm{k}}=$ is the coefficient for the IVs

$\mathrm{u}_{\mathrm{it}}=\mathrm{is}$ the error term

$E_{n=}$ is the entity $n$.

$\gamma_{2}=$ is the coefficient for the binary repressors (entities)

The random effects model is:

$$
\mathrm{Y}_{\mathrm{it}}=\beta \mathrm{X}_{\mathrm{it}}+\alpha+\mathrm{u}_{\mathrm{it}}+\varepsilon_{\mathrm{it}}
$$

In Poisson regression, the paper supposes that the Poisson incidence rate $\boldsymbol{\mu}$ is determined by a set of k regressor variables (the X's). The expression relating these quantities is $\mu$.

$$
\boldsymbol{\mu}=\mathrm{t} \exp \left(\beta_{1} \mathrm{X}_{1}+\beta_{2} \mathrm{X}_{2}+\ldots . .+\beta_{\mathrm{K}} \mathrm{X}_{\mathrm{K}}\right)
$$

$X_{1 \equiv 1}$ and $\beta_{1}$ is called the intercept. The regression coefficients $\beta_{1}, \beta_{2} \ldots . \beta_{\mathrm{k}}$ are unknown parameters that are estimated from a set of data. Their estimates are labeled $b_{1}, b_{2} \ldots b_{k}$. 


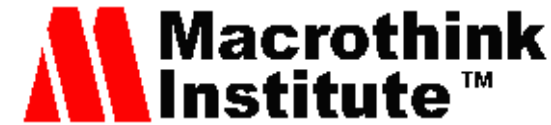

International Journal of Accounting and Financial Reporting

ISSN 2162-3082

Using this notation, the fundamental Poisson regression model for an observation $\mathrm{i}$ is written as

Where,

$$
\mathrm{P}_{\mathrm{r}}\left(\mathrm{Y}_{\mathrm{i}}=\mathrm{y}_{\mathrm{i}} \mid \boldsymbol{\mu}_{\mathrm{I}}, \mathrm{t}_{\mathrm{i}}\right)=\frac{\mathrm{e}^{-\boldsymbol{\mu}_{11}{ }^{\mathrm{t}}\left(\boldsymbol{\mu}_{\mathrm{i}} \mathrm{t}_{\mathrm{i}}\right)^{\mathrm{y}}{ }_{1}}}{\mathrm{Y}_{\mathrm{i}} !}
$$

$\boldsymbol{\mu}_{\mathrm{i}}=\mathrm{t}_{\mathrm{i}} \boldsymbol{\mu}\left(\dot{\mathrm{X}}_{\mathrm{i}} \beta\right)=\mathrm{t}_{\mathrm{i}} \exp \left(\beta_{1} \mathrm{X}_{1 \mathrm{i}}+\beta_{2} \mathrm{X}_{2 \mathrm{i}}+\ldots \ldots+\beta_{\mathrm{K}} \mathrm{X}_{\mathrm{Ki}}\right)$

That is, for a given set of values of the regressor variables, the outcome follows the Poisson distribution.

In the Prais-Winsten the equation is

$$
Y_{t}=\alpha+X_{t} \beta+\varepsilon_{t}
$$

Where $Y_{t}$ is the time series of interest at time, $\beta$ is a vector of coefficients, $X_{t}$ is a matrix of explanatory variables and $\varepsilon_{\mathrm{t}}$ error terms. The error terms can be serially correlated over time $\varepsilon_{\mathrm{t}}=\mathrm{p} \varepsilon_{\mathrm{t}-1}+\mathrm{e}_{\mathrm{t}},|\mathrm{p}|<1$ and $\mathrm{e}_{\mathrm{t}}$ is a white noise.

In the Generalized Method of Moments estimator based on these population moments conditions is the value of $\theta$ that minimizes.

$$
\mathrm{Q}_{\mathrm{n}}(\theta)=\left\{\mathrm{n}_{\mathrm{t}=1}^{\mathrm{n}} \sum \mathrm{f}\left(\mathrm{v}_{\mathrm{t}}, \theta\right)^{\prime}\right\} \mathrm{W}_{\mathrm{n}}\left\{\mathrm{n}^{-1} \sum_{\mathrm{t}=1}^{\mathrm{n}} \mathrm{f}\left(\mathrm{v}_{\mathrm{t}}, \theta\right)\right\}
$$

Where $\mathrm{W}_{\mathrm{n}}$ is a non-negative definite matrix that usually depends on the data but converges to a constant positive definite matrix as $\mathrm{n} \longrightarrow \infty$.

The GEE approach estimates $\beta$ by solving the estimating equations (Liang and Zeger), and (Prentice):

$$
\sum_{\mathrm{i}=1}^{\mathrm{N}} \mathrm{D}_{\mathrm{i}}^{\prime} \mathrm{V}_{\mathrm{i}}^{-1}\left(\mathrm{Y}_{\mathrm{i}}-\boldsymbol{\mu}_{\mathrm{i}}\right)=0
$$

Where $D_{i}=D_{i}(\beta)=\partial \mu_{i}(\beta) / \partial \beta^{\prime}$, and $V_{i}$ is the working covariance matrix of $Y_{i} \cdot V_{i}$ can be expressed in terms of a correlation matrix $R(\alpha): \mathrm{V}_{\mathrm{i}}=\mathrm{A}_{\mathrm{i}}^{1 / 2} \mathrm{R}(\alpha) \mathrm{A}_{\mathrm{i}}^{1 / 2}$ where $\mathrm{A}_{\mathrm{i}}$ is a diagonal matrix with elements $\operatorname{var}\left(\mathrm{Y}_{\mathrm{it}}\right)=\mathrm{V}\left(\mu_{\mathrm{it}}\right)$, specified as functions of the means $\mu_{\mathrm{it}}, \alpha$ is some unknown parameter.

\subsection{Data Sources}

This article has employed panel data for 79 countries over the period from 1998 to 2014 among different developing countries (See in Table 1). Here the FDI which is noted as an dependent variable is measured in current U.S. dollars divided by the host country's total population as the dependent variable, and data come from UNCTAD. Data on FDI are provided by several sources, such as Balance of Payments Statistics Yearbook and 


\section{Ml Macrothink}

International Journal of Accounting and Financial Reporting

ISSN 2162-3082

2018, Vol. 8, No. 4

International Finance Statistics by the International Monetary Fund (IMF), European Union Direct Investment Yearbook by EUROSTAT, World Investment Report by UNCTAD, World Development Indicators by the World Bank, and International Direct Investment Statistics Yearbook by OECD. Only the UNCTAD, OECD, and EUROSTAT offer a sectoral breakdown of FDI flows and stocks. The drawback of using the data from OECD and EUROSTAT is only cover a very limited number of world countries and thus the total direct investment received by any given country cannot be completely assessed. Moreover, the paper is more interested in FDI inflows than FDI stocks because policy recommendations are usually formulated to boost FDI inflows rather than to accumulate FDI stocks for a given period. However, only UNCTAD provides a break down into two different categories: FDI figures for developed and for developing countries that really serve our purpose. Because of making contemplative judgment FDI related data are accumulated from the UNCTAD.

Table 1. List of the countries

Afghanistan, Albania, Algeria, Angola, Argentina, Armenia, Azerbaijan, Bangladesh, Belarus, Benin, Bhutan, Bolivia, Botswana, Bulgaria, Burundi, Cambodia, Chad, Colombia, Comoros, Cuba, Dominica, Ecuador, El Salvador, Ethiopia, Figgie, Gambia, Georgia, Ghana, Grenada, Guatemala, Guinea, Guyana, Haiti, Honduras, Iran, Iraq, Jamaica, Jordan, Kazakhstan, Kenya, Kosovo, Lebanon, Liberia, Libya, Madagascar, Maldives, Mali, Moldova, Mongolia, Morocco, Mozambique, Myanmar, Namibia, Nepal, Nicaragua, Nigeria, Pakistan, Papua New Guinea, Peru, Senegal, Serbia, Sierra Leone, Somalia, South Sudan, Sri Lanka, Sudan, Suriname, Tajikistan, Timor-Leste, Togo, Tonga, Tunisia, Uganda, Ukraine, Venezuela, Vietnam, Yemen, Zambia and Zimbabwe.

\section{Source: Own Calculation}

For the independent variable like institutional quality that is including the six different factors, voice and accountability, political stability and violence, government effectiveness, regulation quality, rules of law and control of corruption. Data are aggregating from the worldwide governance indicators. Here the voice and accountability is not considered for our purpose. Data collection method and research methodology all the things can be access in that particular website: www.govindicators.org.

Here in this study the paper has applied the Index of Economic Freedom provided by Heritage Foundation, for measuring economic freedom that is another independent variable which is included 50 independent variables fall into 10 categories of economic freedom. Each country receives its overall economic freedom score based on the simple average of the 10 individual factor score. Each factor has a unique scale that runs from 1 to 5, where a score of 1 indicates an economic environment that are most conducive to economic freedom and a score of 5 indicates the opposite. 
Table 2. Description of the variable

\begin{tabular}{|c|c|c|c|c|c|}
\hline \multicolumn{3}{|l|}{ Variables } & Description & Source & Expected Sign \\
\hline \multirow[t]{6}{*}{$\begin{array}{l}\text { Dependent } \\
\text { Variables }\end{array}$} & \multicolumn{2}{|c|}{ Foreign Direct Investment } & $\begin{array}{l}\text { Total FDI inflows a host country receives at time } t \text { divided by the host country's } \\
\text { total population (i.e., FDI per capita) }\end{array}$ & UNCTAD,2014 & $(+)$ \\
\hline & \multicolumn{2}{|c|}{$\begin{array}{l}\text { Political Stability (PS) and } \\
\text { absence of violence }\end{array}$} & $\begin{array}{l}\text { Perception of likelihood that the government in power will be destabilized or } \\
\text { overthrown by possibly unconstitutional and/or violent means, including } \\
\text { domestic violence and terrorism. }\end{array}$ & $\begin{array}{l}\text { Worlds governance } \\
\text { Indicator, } 2014\end{array}$ & $(+)$ \\
\hline & \multicolumn{2}{|c|}{ Government Effectiveness } & $\begin{array}{l}\text { The quality of public services, the quality of the civil service and the degree of } \\
\text { its independence from political pressures, the quality of policy formulation and } \\
\text { implementation, and the credibility of the government's commitment to such } \\
\text { policies. }\end{array}$ & $\begin{array}{l}\text { Worlds governance } \\
\text { Indicator, } 2014\end{array}$ & $(+)$ \\
\hline & \multicolumn{2}{|l|}{ Regulatory Quality } & $\begin{array}{l}\text { The ability of the government to formulate and implement sound policies and } \\
\text { regulations that permits and promotes private sector development. }\end{array}$ & $\begin{array}{l}\text { Worlds governance } \\
\text { Indicator, } 2014\end{array}$ & $(+)$ \\
\hline & \multicolumn{2}{|l|}{ Rule of Law (RL) } & $\begin{array}{l}\text { The extent to which agents have confidence in and abide by the rules of society, } \\
\text { and in particular the quality of contract enforcement, the police, and the courts, } \\
\text { as well as the likelihood of crime and violence. }\end{array}$ & $\begin{array}{l}\text { Worlds governance } \\
\text { Indicator, } 2014\end{array}$ & $(+)$ \\
\hline & \multicolumn{2}{|l|}{ Control of Comuption } & $\begin{array}{l}\text { The extent to which public power is exercised for private gain, including both } \\
\text { petty and grand forms of comuption, as well as "capture" of the state by elites } \\
\text { and private interests. }\end{array}$ & $\begin{array}{l}\text { Worlds governance } \\
\text { Indicator, } 2014\end{array}$ & $(+)$ \\
\hline \multirow[t]{8}{*}{$\begin{array}{l}\text { Independent } \\
\text { Variables }\end{array}$} & \multicolumn{2}{|l|}{ Business Freedom } & The ability to generate, operates, and closes up an enterprise quickly and easily. & $\begin{array}{l}\text { Heritage Foundation, } \\
2014\end{array}$ & $(+)$ \\
\hline & \multicolumn{2}{|l|}{ Trade Freedom } & $\begin{array}{l}\text { Trade freedom is measuring in the absence of tariff and non-tariff barriers that } \\
\text { influence on imports and exports of goods and services. }\end{array}$ & $\begin{array}{l}\text { Heritage Foundation, } \\
2014\end{array}$ & $(+)$ \\
\hline & \multicolumn{2}{|l|}{ Government Size } & All government expenditures, including consumption and transfers. & $\begin{array}{l}\text { Heritage Foundation, } \\
2014\end{array}$ & $(+)$ \\
\hline & \multicolumn{2}{|l|}{ Investment Freedom } & An assessment of the free flow of capital. & $\begin{array}{l}\text { Heritage Foundation, } \\
2014\end{array}$ & $(+)$ \\
\hline & \multicolumn{2}{|l|}{ Property Rights } & $\begin{array}{l}\text { An assessment of the aptitude of individuals to accumulate private property, } \\
\text { protected by clear laws that are fully compulsory by the state. }\end{array}$ & $\begin{array}{l}\text { Heritage Foundation, } \\
2014\end{array}$ & $(+)$ \\
\hline & \multicolumn{2}{|c|}{ Freedom from Comuption } & $\begin{array}{l}\text { Quantitative data that evaluate the perception of corruption in the business } \\
\text { environment, including levels of governmental legal, judicial, and administrative } \\
\text { corruption. }\end{array}$ & $\begin{array}{l}\text { Heritage Foundation, } \\
2014\end{array}$ & $(+)$ \\
\hline & \multicolumn{2}{|l|}{ Labour Freedom } & $\begin{array}{l}\text { It is a composite measure of the aptitude of workers and businesses to interact } \\
\text { without restriction by the state. }\end{array}$ & $\begin{array}{l}\text { Heritage Foundation, } \\
2014\end{array}$ & $(+)$ \\
\hline & \multicolumn{2}{|l|}{ Financial Freedom } & $\begin{array}{l}\text { Financial freedom that measure of banking security as well as independence } \\
\text { from government control; state ownership of banks and other financial } \\
\text { institutions. }\end{array}$ & $\begin{array}{l}\text { Heritage Foundation, } \\
2014\end{array}$ & $(+)$ \\
\hline \multicolumn{2}{|c|}{ Fiscal Freedom } & \multicolumn{2}{|r|}{$\begin{array}{l}\text { Fiscal freedom is a measure of the burden of government from the revenue side } \\
\text { and it includes both the tax burden in terms of the top tax rate on income and the } \\
\text { overall amount of tax revenue as a portion of GDP. }\end{array}$} & $\begin{array}{l}\text { Heritage Foundation, } \\
\qquad 2014\end{array}$ & $(+)$ \\
\hline \multicolumn{2}{|c|}{ Monetary Freedom } & \multicolumn{2}{|r|}{$\begin{array}{l}\text { Monetary freedom combines a measure of price stability with an assessment of } \\
\text { price controls. }\end{array}$} & $\begin{array}{l}\text { Heritage Foundation, } \\
2014\end{array}$ & $(+)$ \\
\hline \multicolumn{2}{|c|}{ Democracy } & \multicolumn{2}{|r|}{$\begin{array}{l}\text { Index of Democratization. Index that could vary from } 0 \text { (no democracy) to } 100 \\
\text { (full democracy). }\end{array}$} & $\begin{array}{l}\text { Quality of } \\
\text { Government } \\
\text { Institute }\end{array}$ & $(+)$ \\
\hline
\end{tabular}

\section{Empirical Evidence}

Concentrate on the model specification the following table interprets whether the panel data are stationary or not. For identifying this, five different panel unit test is being accomplished (Levin, Lin and Chu, Breitung, Im, Pesaran and Shin, Fisher-Type test using ADF and PP-test (Maddala and Wu and Choi) and Hadri. Base on the five different type of panel unit root test such as Levin, Lin and Chu, Im, Pesaran and Shin, Fisher-Type test using ADF and PP-test (Maddala and Wu and Choi 2001) and Hadri method the variables are not stationary at a level. 
Table 3. Panel unit root test

\begin{tabular}{|c|c|c|c|c|c|}
\hline Variables & $\begin{array}{l}\text { Levin Lin and } \\
\text { Chu-t test } \\
\text { Values** and } \\
\text { prob }\end{array}$ & $\begin{array}{l}\text { Im, Pesaran and } \\
\text { Shin W-stat test } \\
\text { Values }^{* *} \text { and Prob }\end{array}$ & $\begin{array}{l}\text { ADF-Fisher } \\
\text { Chi-square Test } \\
\text { Values** and } \\
\text { Prob }\end{array}$ & $\begin{array}{l}\text { PP-Fisher Chi- } \\
\text { square Test } \\
\text { Values**and } \\
\text { Prob }\end{array}$ & Hadri \\
\hline Foreign Direct & -2.94310 & -5.68401 & 15.29884 & 26.32540 & 2.38723 \\
\hline Investment & $\mathrm{P}=0.2905$ & $\mathrm{P}=0.1726$ & $\mathrm{P}=0.0894$ & $\mathrm{P}=0.1421$ & $\mathrm{P}=0.0000$ \\
\hline Political & -6.22498 & -16.85721 & 26.93173 & 41.47842 & 3.48325 \\
\hline Stability & $\mathrm{P}=0.0386$ & $\mathrm{P}=0.0389$ & $\mathrm{P}=0.2519$ & $\mathrm{P}=0.3146$ & $\mathrm{P}=0.0000$ \\
\hline Government & -3.28891 & -8.95172 & 15.05144 & 28.92014 & 2.86913 \\
\hline Effectiveness & $\mathrm{P}=0.0256$ & $\mathrm{P}=0.0178$ & $\mathrm{P}=0.0234$ & $\mathrm{P}=0.0331$ & $\mathrm{P}=0.0000$ \\
\hline Regulatory & -4.92176 & 6.99341 & 17.09531 & 28.09974 & 3.09984 \\
\hline Qualities & $\mathrm{P}=0.1529$ & $\mathrm{P}=0.2461$ & $\mathrm{P}=0.1129$ & $\mathrm{P}=0.2582$ & $\mathrm{P}=0.0000$ \\
\hline Rules of Laws & $\begin{array}{l}-6.97182 \\
\mathrm{P}=0.1027\end{array}$ & $\begin{array}{l}7.25114 \\
\mathrm{P}=0.2654\end{array}$ & $\begin{array}{l}19.26703 \\
\mathrm{P}=0.1908\end{array}$ & $\begin{array}{l}27.18513 \\
\mathrm{P}=0.2163\end{array}$ & $\begin{array}{l}3.09144 \\
\mathrm{P}=0.0000\end{array}$ \\
\hline $\begin{array}{l}\text { Control of } \\
\text { Corruption }\end{array}$ & $\begin{array}{l}-5.46562 \\
P=0.1127\end{array}$ & $\begin{array}{l}8.19039 \\
P=0.2540\end{array}$ & $\begin{array}{l}24.17721 \\
P=0.1892\end{array}$ & $\begin{array}{l}29.16371 \\
\mathrm{P}=0.2263\end{array}$ & $\begin{array}{l}3.54109 \\
\mathrm{P}=0.0000\end{array}$ \\
\hline $\begin{array}{l}\text { Business } \\
\text { Freedom }\end{array}$ & $\begin{array}{l}-5.43193 \\
\mathrm{P}=0.0711\end{array}$ & $\begin{array}{l}-3.29851 \\
\mathrm{P}=-3.29851\end{array}$ & $\begin{array}{l}21.14332 \\
\mathrm{P}=21.14332\end{array}$ & $\begin{array}{l}15.16883 \\
\mathrm{P}=15.16883\end{array}$ & $\begin{array}{l}4.27094 \\
P=0.0000\end{array}$ \\
\hline Trade Freedom & $\begin{array}{l}-5.42163 \\
P=0.0429\end{array}$ & $\begin{array}{l}-8.13416 \\
\mathrm{P}=0.2805\end{array}$ & $\begin{array}{l}34.28928 \\
\mathrm{P}=0.0549\end{array}$ & $\begin{array}{l}14.72116 \\
P=0.1304\end{array}$ & $\begin{array}{l}3.29842 \\
\mathrm{P}=0.0000\end{array}$ \\
\hline $\begin{array}{l}\text { Government } \\
\text { Size }\end{array}$ & $\begin{array}{l}-4.92163 \\
P=0.0672\end{array}$ & $\begin{array}{l}-8.24631 \\
\mathrm{P}=0.2137\end{array}$ & $\begin{array}{l}23.15993 \\
P=0.0942\end{array}$ & $\begin{array}{l}37.12046 \\
\mathrm{P}=0.1786\end{array}$ & $\begin{array}{l}2.34173 \\
\mathrm{P}=0.0000\end{array}$ \\
\hline $\begin{array}{l}\text { Investment } \\
\text { Freedom }\end{array}$ & $\begin{array}{l}-7.29884 \\
P=0.0672\end{array}$ & $\begin{array}{l}-19.76118 \\
\mathrm{P}=0.1763\end{array}$ & $\begin{array}{l}22.14729 \\
\mathrm{P}=0.0549\end{array}$ & $\begin{array}{l}15.27661 \\
\mathrm{P}=0.1115\end{array}$ & $\begin{array}{l}2.18992 \\
\mathrm{P}=0.0000\end{array}$ \\
\hline Property Rights & $\begin{array}{l}-4.94116 \\
\mathrm{P}=0.0728\end{array}$ & $\begin{array}{l}-16.29474 \\
\mathrm{P}=0.0672\end{array}$ & $\begin{array}{l}29.18034 \\
\mathrm{P}=0.1529\end{array}$ & $\begin{array}{l}17.72383 \\
\mathrm{P}=0.2783\end{array}$ & $\begin{array}{l}5.46882 \\
\mathrm{P}=0.0000\end{array}$ \\
\hline $\begin{array}{l}\text { Freedom From } \\
\text { Corruption }\end{array}$ & $\begin{array}{l}-7.34731 \\
\mathrm{P}=0.0722\end{array}$ & $\begin{array}{l}-5.63189 \\
P=0.2673\end{array}$ & $\begin{array}{l}27.16720 \\
P=0.1549\end{array}$ & $\begin{array}{l}17.17883 \\
\mathrm{P}=0.2618\end{array}$ & $\begin{array}{l}4.18441 \\
\mathrm{P}=0.0000\end{array}$ \\
\hline Labor Freedom & $\begin{array}{l}-3.29551 \\
P=0.0826\end{array}$ & $\begin{array}{l}-24.16726 \\
P=0.3981\end{array}$ & $\begin{array}{l}28.94825 \\
\mathrm{P}=0.1642\end{array}$ & $\begin{array}{l}34.12772 \\
\mathrm{P}=0.0549\end{array}$ & $\begin{array}{l}4.77009 \\
P=0.0000\end{array}$ \\
\hline $\begin{array}{l}\text { Financial } \\
\text { Freedom }\end{array}$ & $\begin{array}{l}-6.15484 \\
P=0.0621\end{array}$ & $\begin{array}{l}-12.63180 \\
P=0.2198\end{array}$ & $\begin{array}{l}22.15827 \\
\mathrm{P}=0.1219\end{array}$ & $\begin{array}{l}32.25331 \\
\mathrm{P}=0.0622\end{array}$ & $\begin{array}{l}3.68294 \\
P=0.0000\end{array}$ \\
\hline Fiscal Freedom & $\begin{array}{l}-7.24409 \\
P=0.0754\end{array}$ & $\begin{array}{l}-18.54220 \\
P=0.2093\end{array}$ & $\begin{array}{l}34.65319 \\
\mathrm{P}=0.1732\end{array}$ & $\begin{array}{l}21.18742 \\
\mathrm{P}=0.1218\end{array}$ & $\begin{array}{l}3.68294 \\
P=0.0000\end{array}$ \\
\hline $\begin{array}{l}\text { Monetary } \\
\text { Freedom }\end{array}$ & $\begin{array}{l}-4.21774 \\
\mathrm{P}=0.0421\end{array}$ & $\begin{array}{l}-10.56821 \\
\mathrm{P}=0.1204\end{array}$ & $\begin{array}{l}27.92454 \\
\mathrm{P}=0.1572\end{array}$ & $\begin{array}{l}31.66734 \\
\mathrm{P}=0.1925\end{array}$ & $\begin{array}{l}4.6073 \\
P=0.0000\end{array}$ \\
\hline Democracy & $\begin{array}{l}-5.54289 \\
P=0.0572\end{array}$ & $\begin{array}{l}-11.29095 \\
P=0.0729\end{array}$ & $\begin{array}{l}31.43461 \\
\mathrm{P}=0.1928\end{array}$ & $\begin{array}{l}45.29661 \\
P=0.2463\end{array}$ & $\begin{array}{l}4.25186 \\
\mathrm{P}=0.0000\end{array}$ \\
\hline
\end{tabular}

Source: Own Calculation

From the Table 4 concentrate on the five different type of panel unit root test such as Levin, Lin and Chu, Im, Pesaran and Shin, Fisher-Type test using ADF and PP-test (Maddala and Wu and Choi) and Hadri methods the variables are stationary at a first differences. 
Table 4. Panel unit root test

\begin{tabular}{|c|c|c|c|c|c|}
\hline Variables & $\begin{array}{l}\text { Levin Lin and } \\
\text { Chu-t test } \\
\text { Values** and } \\
\text { prob }\end{array}$ & $\begin{array}{l}\text { Im, Pesaran and } \\
\text { Shin W-stat test } \\
\text { Values** and Prob }\end{array}$ & $\begin{array}{l}\text { ADF-Fisher } \\
\text { Chi-square Test } \\
\text { Values** and } \\
\text { Prob }\end{array}$ & $\begin{array}{l}\text { PP-Fisher Chi- } \\
\text { square Test } \\
\text { Values**and } \\
\text { Prob }\end{array}$ & Hadri \\
\hline Foreign Direct & -8.32117 & -4.27992 & 21.45184 & 31.68214 & 0.73119 \\
\hline Investment & $\mathrm{P}=0.0000$ & $\mathrm{P}=0.0001$ & $\mathrm{P}=0.0000$ & $\mathrm{P}=0.0007$ & $\mathrm{P}=0.2984$ \\
\hline Political & -3.65182 & -6.75672 & 27.29841 & 32.15909 & 0.72194 \\
\hline Stability & $\mathrm{P}=0.0005$ & $\mathrm{P}=0.0008$ & $\mathrm{P}=0.0035$ & $\mathrm{P}=0.0068$ & $\mathrm{P}=0.2908$ \\
\hline Government & -4.92472 & -8.92167 & 16.92413 & 23.09883 & 0.87122 \\
\hline Effectiveness & $\mathrm{P}=0.0004$ & $\mathrm{P}=0.0002$ & $\mathrm{P}=0.0026$ & $\mathrm{P}=0.0031$ & $\mathrm{P}=0.1590$ \\
\hline Regulatory & -5.52103 & -6.84398 & 32.16755 & 37.09092 & 0.71453 \\
\hline Qualities & $\mathrm{p}=0.0003$ & $\mathrm{P}=0.0005$ & $\mathrm{P}=0.0019$ & $\mathrm{P}=0.0043$ & $\mathrm{P}=0.2319$ \\
\hline Rules of Laws & $\begin{array}{l}-6.75113 \\
p=0.0004\end{array}$ & $\begin{array}{l}-7.01322 \\
\mathrm{P}=0.0006\end{array}$ & $\begin{array}{l}30.10912 \\
\mathrm{P}=0.0025\end{array}$ & $\begin{array}{l}35.18721 \\
\mathrm{P}=0.0051\end{array}$ & $\begin{array}{l}0.85882 \\
\mathrm{P}=0.2466\end{array}$ \\
\hline $\begin{array}{l}\text { Control of } \\
\text { Corruption }\end{array}$ & $\begin{array}{l}-8.54109 \\
p=0.0007\end{array}$ & $\begin{array}{l}-6.24772 \\
P=0.0003\end{array}$ & $\begin{array}{l}31.46172 \\
P=0.0028\end{array}$ & $\begin{array}{l}41.58781 \\
P=0.0043\end{array}$ & $\begin{array}{l}0.89711 \\
\mathrm{P}=0.2608\end{array}$ \\
\hline $\begin{array}{l}\text { Business } \\
\text { Freedom }\end{array}$ & $\begin{array}{l}-5.46109 \\
p=0.0003\end{array}$ & $\begin{array}{l}-6.75941 \\
P=0.0005\end{array}$ & $\begin{array}{l}34.18094 \\
\mathrm{P}=0.0019\end{array}$ & $\begin{array}{l}37.65902 \\
\mathrm{P}=0.0054\end{array}$ & $\begin{array}{l}0.82532 \\
\mathrm{P}=0.2137\end{array}$ \\
\hline Trade Freedom & $\begin{array}{l}-3.11729 \\
\mathrm{P}=0.0004\end{array}$ & $\begin{array}{l}-5.16193 \\
\mathrm{P}=0.0003\end{array}$ & $\begin{array}{l}32.29031 \\
\mathrm{P}=0.0011\end{array}$ & $\begin{array}{l}41.11294 \\
\mathrm{P}=0.0018\end{array}$ & $\begin{array}{l}0.79091 \\
\mathrm{P}=0.1984\end{array}$ \\
\hline $\begin{array}{l}\text { Government } \\
\text { Size }\end{array}$ & $\begin{array}{l}-2.90318 \\
\mathrm{P}=0.0002\end{array}$ & $\begin{array}{l}-8.22249 \\
\mathrm{P}=0.0009\end{array}$ & $\begin{array}{l}16.27831 \\
\mathrm{P}=0.0034\end{array}$ & $\begin{array}{l}24.27943 \\
\mathrm{P}=0.0057\end{array}$ & $\begin{array}{l}0.68836 \\
\mathrm{P}=0.3106\end{array}$ \\
\hline $\begin{array}{l}\text { Investment } \\
\text { Freedom }\end{array}$ & $\begin{array}{l}-3.44841 \\
\mathrm{P}=0.0003\end{array}$ & $\begin{array}{l}-6.74209 \\
P=0.0009\end{array}$ & $\begin{array}{l}21.0915 \\
P=0.0041\end{array}$ & $\begin{array}{l}31.67093 \\
P=0.0069\end{array}$ & $\begin{array}{l}0.74167 \\
P=0.2492\end{array}$ \\
\hline Property Rights & $\begin{array}{l}-4.19631 \\
\mathrm{P}=0.0002\end{array}$ & $\begin{array}{l}-8.46318 \\
P=0.0011\end{array}$ & $\begin{array}{l}24.29086 \\
P=0.0029\end{array}$ & $\begin{array}{l}31.52981 \\
\mathrm{P}=0.0045\end{array}$ & $\begin{array}{l}0.81670 \\
P=0.2781\end{array}$ \\
\hline $\begin{array}{l}\text { Freedom From } \\
\text { Corruption }\end{array}$ & $\begin{array}{l}-8.17031 \\
\mathrm{P}=0.0006\end{array}$ & $\begin{array}{l}-11.78109 \\
\mathrm{P}=0.0018\end{array}$ & $\begin{array}{l}36.42156 \\
P=0.0059\end{array}$ & $\begin{array}{l}41.26193 \\
\mathrm{P}=0.0077\end{array}$ & $\begin{array}{l}0.54193 \\
\mathrm{P}=0.2094\end{array}$ \\
\hline Labor Freedom & $\begin{array}{l}-7.21093 \\
P=0.0007\end{array}$ & $\begin{array}{l}-11.54194 \\
\mathrm{P}=0.0013\end{array}$ & $\begin{array}{l}25.60912 \\
P=0.0061\end{array}$ & $\begin{array}{l}37.55190 \\
\mathrm{P}=0.0082\end{array}$ & $\begin{array}{l}0.51861 \\
P=0.2894\end{array}$ \\
\hline $\begin{array}{l}\text { Financial } \\
\text { Freedom }\end{array}$ & $\begin{array}{l}-5.42885 \\
\mathrm{P}=0.0006\end{array}$ & $\begin{array}{l}-9.39081 \\
P=0.0011\end{array}$ & $\begin{array}{l}21.44093 \\
\mathrm{P}=0.0062\end{array}$ & $\begin{array}{l}38.54817 \\
\mathrm{P}=0.0081\end{array}$ & $\begin{array}{l}0.61204 \\
P=0.1834\end{array}$ \\
\hline Fiscal Freedom & $\begin{array}{l}-3.40092 \\
\mathrm{P}=0.0004\end{array}$ & $\begin{array}{l}-7.22807 \\
\mathrm{P}=0.0017\end{array}$ & $\begin{array}{l}18.41063 \\
\mathrm{P}=0.0061\end{array}$ & $\begin{array}{l}25.49860 \\
\mathrm{P}=0.0079\end{array}$ & $\begin{array}{l}0.63428 \\
\mathrm{P}=0.2317\end{array}$ \\
\hline $\begin{array}{l}\text { Monetary } \\
\text { Freedom }\end{array}$ & $\begin{array}{l}-6.16425 \\
P=0.0004\end{array}$ & $\begin{array}{l}-9.21094 \\
P=0.0009\end{array}$ & $\begin{array}{l}19.54831 \\
\mathrm{P}=0.0025\end{array}$ & $\begin{array}{l}36.48093 \\
P=0.0063\end{array}$ & $\begin{array}{l}0.67041 \\
P=0.3572\end{array}$ \\
\hline Democracy & $\begin{array}{l}-5.28462 \\
P=0.0003\end{array}$ & $\begin{array}{l}-8.34992 \\
P=0.0007\end{array}$ & $\begin{array}{l}22.49821 \\
P=0.0021\end{array}$ & $\begin{array}{l}34.15382 \\
P=0.0054\end{array}$ & $\begin{array}{l}0.54926 \\
P=0.1492\end{array}$ \\
\hline
\end{tabular}

Source: Own Calculation

Table 5. Pedroni residual co-integration test

\begin{tabular}{|c|c|c|c|}
\hline \multirow{3}{*}{$\begin{array}{c}\text { Test } \\
\text { Method }\end{array}$} & \multicolumn{3}{|c|}{ Pedroni Residual Co-integration Test } \\
\hline & & & \\
\hline & No deterministic trend & $\begin{array}{c}\text { Deterministic intercept } \\
\text { and trend }\end{array}$ & $\begin{array}{c}\text { No deterministic intercept or } \\
\text { trend }\end{array}$ \\
\hline \multirow[t]{2}{*}{ Panel v-statistic } & -0.058830 & -3.729518 & -0.230017 \\
\hline & $\mathrm{P}=0.5904$ & $\mathrm{P}=0.2604$ & $\mathrm{P}=0.1729$ \\
\hline \multirow[t]{2}{*}{ Panel rho-Statistic } & -2.159273 & 7.260952 & -0.243681 \\
\hline & $\mathrm{P}=0.3419$ & $\mathrm{P}=0.2188$ & $\mathrm{P}=0.1319$ \\
\hline \multirow{2}{*}{ Panel PP-Statistic } & -6.551803 & -6.771951 & -4.119271 \\
\hline & $\mathrm{P}=0.0026$ & $\mathrm{P}=0.1329$ & $\mathrm{P}=0.0046$ \\
\hline \multirow{2}{*}{$\begin{array}{c}\text { Panel ADF- } \\
\text { Statistic }\end{array}$} & -4.367216 & -5.431183 & 6.941803 \\
\hline & $\mathrm{P}=0.0030$ & $\mathrm{P}=0.3417$ & $\mathrm{P}=0.0041$ \\
\hline \multirow{2}{*}{$\begin{array}{c}\text { Group rho- } \\
\text { Statistic }\end{array}$} & 0.289418 & 3.621193 & 4.944172 \\
\hline & $\mathrm{P}=0.2754$ & $\mathrm{P}=0.3992$ & $\mathrm{P}=0.3679$ \\
\hline \multirow{2}{*}{$\begin{array}{l}\text { Group PP- } \\
\text { Statistic }\end{array}$} & -4.941826 & -3.541183 & -4.380091 \\
\hline & $\mathrm{P}=0.0009$ & $\mathrm{P}=0.0007$ & $\mathrm{P}=0.0017$ \\
\hline \multirow{2}{*}{$\begin{array}{l}\text { Group ADF- } \\
\text { Statistic }\end{array}$} & -4.199274 & -3.328841 & -2.411206 \\
\hline & $\mathrm{P}=0.0008$ & $\mathrm{P}=0.0031$ & $\mathrm{P}=0.0021$ \\
\hline
\end{tabular}

Source: Own Calculation 


\section{MIMacrothink}

International Journal of Accounting and Financial Reporting

ISSN 2162-3082

2018, Vol. 8, No. 4

The Table 5 highlights the pedroni cointegration test. From the no deterministic trends there are 7 different and separate outcomes. Out of 7 outcomes, 3 outcomes interpret that the paper has accepted the null hypothesis $\left(\mathrm{H}_{0}=\right.$ No co-integration), because the $\mathrm{p}$ value is $>5$. On the other hand 4 outcomes illustrates that reject the null hypothesis and accept the alternative hypothesis. Therefore it is to be noted that base on the no deterministic trend elucidates that the variables are cointegrate. On the other hand from the deterministic intercept and trends way out of 7 outcomes 5 outcomes interpret that accept the null hypothesis $\left(\mathrm{H}_{0}=\right.$ No Co-integration), because the $\mathrm{p}$ value is $>5$. On the other hand 2 outcomes illustrates that reject the null hypothesis, it means that accept the alternative hypothesis. Therefore it is to be noted that base on the deterministic intercept and trend elucidate that the variables are not cointegrate. From the no deterministic intercept and trends out of 7 outcomes, 4 outcomes interpret that reject the null hypothesis $\left(\mathrm{H}_{0}=\right.$ No integration), because the $\mathrm{p}$ value is $<5$. On the other hand 3 outcomes illustrates that accept the null hypothesis, it means that reject the alternative hypothesis Therefore it is to be noted that base on the no deterministic intercept and trend method elucidates that the variables are cointegrated. It means that two different methods out of three of the Pedroni Residual Cointegration Test the variables are cointegrate. Another lucid method (Kao Residual Cointegration) is used to estimates whether the variables are cointegrate. From the table: 6 it exhibits that the p value is less than 5\%, means it reject the null hypothesis $\left(\mathrm{H}_{0=}\right.$ No co-integration).

Table 6. Kao residual co-integration test

\begin{tabular}{lll}
\hline & t-Statistic & Prob. \\
\cline { 2 - 3 } ADF & & \\
\hline & -7.219945 & 0.0016 \\
\hline Residual variance & 8317.903 & \\
\cline { 2 - 3 } HAC variance & 218.3199 & \\
\hline
\end{tabular}

Source: Own Calculation

From the Table 7 illustrates that $\mathrm{C}(1)$ means speed of adjustment towards long run equilibrium but it must me significant and the sign must be negative. There is long run causality from the variables such as FDI, political stability, government effectiveness, regulatory qualities, rules of law, control of corruption, business freedom, trade freedom, government size, investment freedom, property rights, freedom from corruption, labor freedom, financial freedom, fiscal freedom, monetary freedom and democracy. 
Table 7. Vector error correction model using least squares method

\begin{tabular}{lllll}
\hline Variable & Coefficient & Std.Error & t-statistics & Prob. \\
\hline $\mathrm{C}(1)$ & -21.921822 & 4.103572 & 2.976324 & 0.0072 \\
\hline $\mathrm{C}(2)$ & 51.941092 & 34.296092 & 2.434621 & 0.0095 \\
\hline $\mathrm{C}(3)$ & 69.45514 & 24.321098 & 3.834392 & 0.0043 \\
\hline $\mathrm{C}(4)$ & 75.830917 & 37.192983 & 1.515258 & 0.0061 \\
\hline $\mathrm{C}(5)$ & 61.908813 & 41.013346 & 1.509479 & 0.0049 \\
\hline $\mathrm{C}(6)$ & 72.153328 & 45.298416 & 1.592844 & 0.0217 \\
\hline $\mathrm{C}(7)$ & 87.162652 & 53.154672 & 2.501315 & 0.0326 \\
\hline $\mathrm{C}(8)$ & 55.602284 & 19.113441 & 2.909067 & 0.0562 \\
\hline $\mathrm{C}(9)$ & 124.431962 & 42.496539 & 3.179654 & 0.0865 \\
\hline $\mathrm{C}(10)$ & 112.726615 & 54.392092 & 3.380103 & 0.0946 \\
\hline $\mathrm{C}(11)$ & 153.618214 & 39.311549 & 5.358305 & 0.0328 \\
\hline $\mathrm{C}(12)$ & 142.869213 & 78.396613 & 1.874214 & 0.0463 \\
\hline $\mathrm{C}(13)$ & 120.357146 & 95.236394 & 1.360480 & 0.0288 \\
\hline $\mathrm{C}(14)$ & 52.736803 & 49.210993 & 1.164349 & 0.0050 \\
\hline $\mathrm{C}(15)$ & 113.514662 & 126.254902 & 1.752132 & 0.0088 \\
\hline $\mathrm{C}(16)$ & 81.730152 & 138.132547 & 1.485212 & 0.0031 \\
\hline $\mathrm{C}(17)$ & 127.117894 & 134.119832 & 1.038022 & 0.0232 \\
\hline $\mathrm{C}(18)$ & 145.673702 & 101.138546 & 1.010440 & 0.0167 \\
\hline $\mathrm{C}(19)$ & 131.581337 & 126.102392 & 1.063884 & 0.0328 \\
\hline $\mathrm{C}(20)$ & 66.289148 & 72.143109 & 1.055356 & 0.0263 \\
\hline $\mathrm{C}(21)$ & 81.441729 & 34.347341 & 2.461939 & 0.0434 \\
\hline $\mathrm{C}(22)$ & 108.805522 & 66.223091 & 1.711207 & 0.0245 \\
\hline $\mathrm{C}(23)$ & 80.215801 & 42.198057 & 2.234197 & 0.0382 \\
\hline $\mathrm{C}(24)$ & 79.254517 & 61.298513 & 1.187794 & 0.0015 \\
\hline $\mathrm{C}(25)$ & 35.108214 & 29.843619 & 1.047421 & 0.0196 \\
\hline $\mathrm{C}(26)$ & 31.091606 & 22.935147 & 1.360872 & 0.0143 \\
\hline $\mathrm{C}(27)$ & 22.147318 & 17.295629 & 1.280515 & 0.0041 \\
\hline $\mathrm{C}(28)$ & 27.894142 & 19.241556 & 1.449682 & 0.0035 \\
\hline $\mathrm{C}(29)$ & 31.211816 & 25.884135 & 1.205828 & 0.0025 \\
\hline $\mathrm{C}(30)$ & 24.051941 & 12.165294 & 1.977094 & 0.0019 \\
\hline $\mathrm{C}(31)$ & 19.931725 & 11.628413 & 1.714053 & 0.0125 \\
\hline $\mathrm{C}(32)$ & 15.843228 & 10.286653 & 1.540173 & 0.0071 \\
\hline $\mathrm{C}(33)$ & 14.170342 & 12.378315 & 1.144771 & 0.0019 \\
\hline $\mathrm{C}(34)$ & 15.981124 & 11.241702 & 1.421592 & 0.0017 \\
\hline $\mathrm{C}(35)$ & 18.761280 & 10.856216 & 1.728160 & 0.0026 \\
\hline & & & & \\
\hline & & & & \\
\hline
\end{tabular}

It interprets that the independent variables such as political stability, government effectiveness, regulatory qualities, rules of law, control of corruption, business freedom, trade freedom, government size, investment freedom, property rights, freedom from corruption, labor freedom, financial freedom, fiscal freedom, monetary freedom and democracy have an influence on the dependent variable such as foreign direct investment (FDI).

The different variables like political stability, government effectiveness, regulatory qualities, rules of law, control of corruption, business freedom, trade freedom, government size, investment freedom, property rights, freedom from corruption, labor freedom, financial freedom, fiscal freedom, monetary freedom and democracy have an influence on the dependent variable such as FDI in the short run. For measuring this Wald Statistics has used. Here, $C(4)=C(5)=0$ meaning that there is no short run causality running from political stability to FDI. $\mathrm{C}(6)=\mathrm{C}(7)=0$ meaning that there is no short run causality running from government effectiveness to FDI. $C(8)=C(9)=0$ meaning that there is no short run causality running from regulatory qualities to FDI. $\mathrm{C}(10)=\mathrm{C}(11)=0$ meaning that there is no short run causality running from rules of law to FDI. $\mathrm{C}(12)=\mathrm{C}(13)=0$ meaning that there is no short run causality running from control of corruption to FDI. $C(14)=C(15)=0$ meaning that there 
is no short run causality running from business freedom to FDI. $\mathrm{C}(16)=\mathrm{C}(17)=0$ meaning that there is no short run causality running from trade freedom to FDI. $\mathrm{C}(18)=\mathrm{C}(19)=0$ meaning that there is no short run causality running from government size to FDI. $\mathrm{C}(20)$ $=\mathrm{C}(21)=0$ meaning that there is no short run causality running from investment freedom to FDI. $\mathrm{C}(22)=\mathrm{C}(23)=0$ meaning that there is no short run causality running from property rights to FDI. $\mathrm{C}(24)=\mathrm{C}(25)=0$ meaning that there is no short run causality running from freedom from corruption to FDI. $\mathrm{C}(26)=\mathrm{C}(27)=0$ meaning that there is no short run causality running from labor freedom to FDI. $\mathrm{C}(28)=\mathrm{C}(29)=0$ meaning that there is no short run causality running from financial freedom to $\mathrm{FDI}$. $\mathrm{C}(30)=\mathrm{C}(31)=0$ meaning that there is no short run causality running from fiscal freedom to FDI. $\mathrm{C}(32)=\mathrm{C}(33)=0$ meaning that there is no short run causality running from monetary freedom to FDI. $C(34)=C(35)=0$ meaning that there is no short run causality running from democracy to FDI

Table 8. Wald statistics

\begin{tabular}{|c|c|c|}
\hline Independent Variable & Hypothesis & Prob \\
\hline Political Stability & $C(4)=C(5)=0$ & 0.0005 \\
\hline Government effectiveness & $C(6)=C(7)=0$ & 0.0003 \\
\hline Regulatory Qualities & $\mathrm{C}(8)=\mathrm{C}(9)=0$ & 0.0003 \\
\hline Rules of laws & $C(10)=C(11)=0$ & 0.0006 \\
\hline Control of corruption & $C(12)=C(13)=0$ & 0.0004 \\
\hline Business Freedom & $C(14)=C(15)=0$ & 0.0005 \\
\hline Trade Freedom & $C(16)=C(17)=0$ & 0.0005 \\
\hline Government Size & $\mathrm{C}(18)=\mathrm{C}(19)=0$ & 0.0004 \\
\hline Investment Freedom & $C(20)=C(21)=0$ & 0.0006 \\
\hline Property Rights & $C(22)=C(23)=0$ & 0.0004 \\
\hline Freedom from Corruption & $C(24)=C(25)=0$ & 0.0004 \\
\hline Labor Freedom & $C(26)=C(27)=0$ & 0.0008 \\
\hline Financial Freedom & $\mathrm{C}(28)=\mathrm{C}(29)=0$ & 0.0007 \\
\hline Fiscal Freedom & $C(30)=C(31)=0$ & 0.0004 \\
\hline Monetary Freedom & $\mathrm{C}(32)=\mathrm{C}(33)=0$ & 0.0005 \\
\hline Democracy & $C(34)=C(35)=0$ & 0.0005 \\
\hline
\end{tabular}

Source: Own Calculation 


\section{MInstitute ${ }^{\text {Mink }}$}

International Journal of Accounting and Financial Reporting

ISSN 2162-3082

From the table it is explore that the $\mathrm{P}$ values of each of the independent variables are less than $5 \%$. It means that there is a short run causality running from the variables like political stability, government effectiveness, regulatory qualities, rules of law, control of corruption, business freedom, trade freedom, government size, investment freedom, property rights, freedom from corruption, labor freedom, financial freedom, fiscal freedom, monetary freedom and democracy to FDI.

From the Pooled OLS method, the impacts of all the variables under the institutional quality are explored to be positive and significant. In the case of political stability and absence of violence the coefficient implies that a one standard deviation improvement in political stability increases FDI by $24.6 \%$. The coefficient of government effectiveness implies that a one standard deviation improvement in government effectiveness increases FDI by $31.6 \%$. Another variable under the institutional quality, of course the regulatory quality, the coefficient of implies that a one standard deviation improvement in regulatory quality increases FDI by $12.8 \%$. In the case of rules of law the coefficient implies that a one standard deviation improvement in rules of law increases FDI by $23.9 \%$. The coefficient of control of corruption implies that a one standard deviation improvement in control of corruption increases FDI by $28.4 \%$.

The impact of all the variables under the economic freedom is also explored to be positive and significant. In the case of business freedom the coefficient implies that a one standard deviation improvement in business freedom increases FDI by $28.4 \%$. The coefficient of trade freedom implies that a one standard deviation improvement in business freedom increases FDI by $32.7 \%$. Another variable under the economic freedom the coefficient of government size implies that a one standard deviation improvement in government size increases FDI by $29.5 \%$. In the case of investment freedom the coefficient implies that a one standard deviation improvement in investment freedom increases FDI by $22.8 \%$. On the concentration of the property rights the coefficient implies that a one standard deviation improvement in property rights increases FDI by $29.0 \%$. The coefficient of freedom from corruption implies that a one standard deviation improvement in freedom from corruption increases FDI by $36.4 \%$. In the case of labor freedom the coefficient implies that a one standard deviation improvement in business freedom increases FDI by 29.3\%. In the case of financial freedom the coefficient implies that a one standard deviation improvement in financial freedom increases FDI by $37.5 \%$. The coefficient of fiscal freedom implies that a one standard deviation improvement in fiscal freedom increases FDI by $46.1 \%$. In the case of monetary freedom the coefficient implies that a one standard deviation improvement in monetary freedom increases FDI by $38.2 \%$. 


\section{Mll Macrothink}

International Journal of Accounting and Financial Reporting

ISSN 2162-3082

2018, Vol. 8, No. 4

Table 9. Pooled OLS

\begin{tabular}{|c|c|c|c|c|c|c|c|c|c|c|c|c|c|c|c|}
\hline Estimation Method & & & & & & & $\mathrm{POO}$ & LED OLS & & & & & & & \\
\hline $\begin{array}{l}\text { Independent } \\
\text { Variable }\end{array}$ & 1 & 2 & 3 & 4 & 5 & 6 & 7 & 8 & 9 & 10 & 11 & 12 & 13 & 14 & 15 \\
\hline Political Stability & $\begin{array}{l}0.246 \\
(2.924)^{* *}\end{array}$ & & & & & & & & & & & & & & \\
\hline $\begin{array}{l}\text { Govermment } \\
\text { effective }\end{array}$ & & $\begin{array}{l}0.316 \\
(2.471)^{* *}\end{array}$ & & & & & & & & & & & & & \\
\hline Regulatory Quality & & & $\begin{array}{l}0.128 \\
(2.251)^{* *}\end{array}$ & & & & & & & & & & & & \\
\hline Rules of Law & & & & $\begin{array}{l}0.239 \\
(2.628)^{* *}\end{array}$ & & & & & & & & & & & \\
\hline $\begin{array}{l}\text { Control of } \\
\text { Comuption }\end{array}$ & & & & & $\begin{array}{l}0.377 \\
(2.892)^{* * *}\end{array}$ & & & & & & & & & & \\
\hline Business Freedom & & & & & & $\begin{array}{l}0.284 \\
(2.116)^{*} \\
\end{array}$ & & & & & & & & & \\
\hline Trade Freedom & & & & & & & $\begin{array}{l}0.327 \\
(2.693)^{* *}\end{array}$ & & & & & & & & \\
\hline Government Size & & & & & & & & $\begin{array}{l}0.295 \\
(2.195)^{* *}\end{array}$ & & & & & & & \\
\hline Investment Freedom & & & & & & & & & $\begin{array}{l}0.228 \\
(2.115)^{* *}\end{array}$ & & & & & & \\
\hline Property Rights & & & & & & & & & & $\begin{array}{l}0.290 \\
(2.021)^{* *}\end{array}$ & & & & & \\
\hline $\begin{array}{l}\text { Freedom From } \\
\text { corruption }\end{array}$ & & & & & & & & & & & $\begin{array}{l}0.364 \\
(2.503)^{* * *}\end{array}$ & & & & \\
\hline Labor Freedom & & & & & & & & & & & & $\begin{array}{l}0.293 \\
(2.150)^{* * *}\end{array}$ & & & \\
\hline Financial Freedom & & & & & & & & & & & & & $\begin{array}{l}0.375 \\
(3.021)^{* *}\end{array}$ & & \\
\hline Fiscal Freedom & & & & & & & & & & & & & & $\begin{array}{l}0.461 \\
(2.298)^{* *}\end{array}$ & \\
\hline Monetary Freedom & & & & & & & & & & & & & & & $\begin{array}{c}0.382 \\
(2.694)^{* *}\end{array}$ \\
\hline DEMOC & $\begin{array}{c}0.633 \\
(1.269)^{* *}\end{array}$ & $\begin{array}{l}0.581 \\
(1.542)^{* *}\end{array}$ & $\begin{array}{l}0.477 \\
(1.529)^{* *}\end{array}$ & $\begin{array}{l}0.325 \\
(1.650)^{* *}\end{array}$ & $\begin{array}{c}0.441 \\
* \quad(1.638)^{* *} \\
\end{array}$ & $\begin{array}{l}0.528 \\
(1.725)^{* *}\end{array}$ & $\begin{array}{l}0.639 \\
(1.604)^{* *}\end{array}$ & $\begin{array}{l}0.593 \\
(1.663)^{* *}\end{array}$ & $\begin{array}{l}0.527 \\
(1.526)^{* *}\end{array}$ & $\begin{array}{l}0.613 \\
(1.829)^{* *}\end{array}$ & $\begin{array}{l}0.662 \\
(1.559)^{* *}\end{array}$ & $\begin{array}{l}0.725 \\
(1.628)^{* *}\end{array}$ & $\begin{array}{c}0.549 \\
(1.714)^{* *}\end{array}$ & $\begin{array}{c}0.416 \\
(1.558)^{* *}\end{array}$ & $\begin{array}{c}0.447 \\
(1.673)^{* *}\end{array}$ \\
\hline
\end{tabular}

Source: Own Calculation

In the first column of the table: 10 here presented the GLS estimates. The impacts of all the variables under the institutional qualities are positive and significant. In the case of political stability, government effectiveness, regulatory qualities, rules of law and control of corruption the coefficient implies that a one standard deviation improvement in the political stability, government effectiveness, regulatory qualities, rules of law and control of corruption increases FDI by $24.19 \%, 15.92 \%, 12.86 \%, 19.25 \%$ and $21.73 \%$ respectively and on the other hand the impact of all the variables under the economic freedom is positive and significant. In the case of business freedom the coefficient implies that a one standard deviation improvement in business freedom increases FDI by $7.29 \%$. Other different variables like trade freedom, government size, investment freedom, property rights, freedom from corruption, labor freedom, financial freedom, fiscal freedom and monetary freedom the coefficient implies that a one standard deviation improvement in trade freedom, government size, investment freedom, property rights, freedom from corruption, labor freedom, financial freedom, fiscal freedom and monetary freedom increases FDI by 5.83\%, 7.21\%, 8.22\%, $7.05 \%, 6.82 \%, 5.84 \%, 6.92 \%, 5.21 \%$ and $5.32 \%$ respectively. 
Table 10. Generalized least square and feasible generalized least square method

\begin{tabular}{|c|c|c|}
\hline Independent Variables & GLS & FGLS \\
\hline Political Stability & $\begin{array}{l}0.2419^{* *} \\
(0.137)\end{array}$ & $\begin{array}{l}0.1952^{* * *} \\
(0.182)\end{array}$ \\
\hline Government effective & $\begin{array}{l}0.1592^{\text {*** }} \\
(0.184)\end{array}$ & $\begin{array}{l}0.1784^{* * *} \\
(0.217) \\
\end{array}$ \\
\hline Regulatory Quality & $\begin{array}{l}0.1286^{* *} \\
(0.160)\end{array}$ & $\begin{array}{l}0.1528^{* * *} \\
(0.174)\end{array}$ \\
\hline Rules of Law & $\begin{array}{l}0.1925^{* * *} \\
(0.207)\end{array}$ & $\begin{array}{l}0.2361^{* * *} \\
(0.256)\end{array}$ \\
\hline Control of Corruption & $\begin{array}{l}0.2173^{* *} \\
(0.194)\end{array}$ & $\begin{array}{l}0.2489^{* * *} \\
(0.248)\end{array}$ \\
\hline Business Freedom & $\begin{array}{l}0.0729^{*} \\
(0.116)\end{array}$ & $\begin{array}{l}0.0952^{*} \\
(0.194) \\
\end{array}$ \\
\hline Trade Freedom & $\begin{array}{l}0.0583^{*} \\
(0.138)\end{array}$ & $\begin{array}{l}0.0961^{*} \\
(0.175)\end{array}$ \\
\hline Government Size & $\begin{array}{l}0.0721^{*} \\
(0.161)\end{array}$ & $\begin{array}{l}0.1021^{*} \\
(0.207)\end{array}$ \\
\hline Investment Freedom & $\begin{array}{l}0.0822^{* * *} \\
(0.184)\end{array}$ & $\begin{array}{l}0.0981^{\text {*** }} \\
(0.252) \\
\end{array}$ \\
\hline Property Rights & $\begin{array}{l}0.0705^{\text {*** }} \\
(0.164)\end{array}$ & $\begin{array}{l}0.0937^{\text {*** }} \\
(0.214)\end{array}$ \\
\hline Freedom From Corruption & $\begin{array}{l}0.0682^{*} \\
(0.195)\end{array}$ & $\begin{array}{l}0.1294^{*} \\
(0.267) \\
\end{array}$ \\
\hline Labor Freedom & $\begin{array}{l}0.0584^{*} \\
(0.168)\end{array}$ & $\begin{array}{l}0.0926^{*} \\
(0.193)\end{array}$ \\
\hline Financial Freedom & $\begin{array}{l}0.0692^{* * *} \\
(0.127)\end{array}$ & $\begin{array}{l}0.0944^{* * *} \\
(0.182)\end{array}$ \\
\hline Fiscal Freedom & $\begin{array}{l}0.0521^{*} \\
(0.139)\end{array}$ & $\begin{array}{l}0.0837^{*} \\
(0.182)\end{array}$ \\
\hline Monetary Freedom & $\begin{array}{l}0.0532^{*} \\
(0.173)\end{array}$ & $\begin{array}{l}0.0826^{*} \\
(0.248) \\
\end{array}$ \\
\hline DEMOC & $\begin{array}{l}0.0281^{\text {*** }} \\
(0.132)\end{array}$ & $\begin{array}{l}0.0325^{* * *} \\
(0.195) \\
\end{array}$ \\
\hline Constant & $\begin{array}{l}0.2394 \\
(0.341) \\
\end{array}$ & $\begin{array}{l}0.3214 \\
(0.430)\end{array}$ \\
\hline Number of Observation & 768 & 768 \\
\hline Wald chi $2(8)$ & 107.69 & 217.34 \\
\hline Prob $>\operatorname{chi} 2$ & 0.0000 & 0.0000 \\
\hline
\end{tabular}

Source: Own Calculation

In the Second column of the Table 10 presented the FGLS estimates. The impacts of all the variables under the institutional qualities are positive and significant. The coefficient of the political stability implies that a one standard deviation improvement in the political stability increases FDI by $19.52 \%$ and the value is slightly lower from the GLS and the rest of the variables are higher from the GLS. The impact of all the variables under the economic freedom is positive and significant. Here all the variables under the economic freedom like business freedom, trade freedom, government size, investment freedom, property rights, freedom from corruption, labor freedom, financial freedom, fiscal freedom, and monetary freedom the coefficient implies that a one standard deviation improvement in business freedom, trade freedom, government size, investment freedom, property rights, freedom from corruption, labor freedom, financial freedom, fiscal freedom and monetary freedom increases FDI by $9.52 \%, 9.61 \%, 10.21 \%, 9.81 \%, 9.37 \%, 12.94 \%, 9.26 \%, 9.44 \%, 8.37 \%$ and $8.26 \%$ respectively, it means that the value is higher from the GLS.

According to the OLS estimates from the Table 11, the impact of all the variables under the institutional quality is positive and significant. In the case of political stability the coefficient 
implies that a one standard deviation improvement in political stability increases FDI by $18.7 \%$. On the concentration of the government effectiveness, the coefficient implies that a one standard deviation improvement in government effectiveness increases FDI by $22.1 \%$. Other different variables like regulatory quality, rules of law and control of corruption the coefficient implies that a one standard deviation improvement in regulatory quality, rules of law and control of corruption increases FDI by $14.3 \%, 14.8 \%$ and $21.6 \%$ respectively.

The impact of all the variables under the economic freedom is positive and significant. In the case of business freedom the coefficient implies that a one standard deviation improvement in business freedom increases FDI by $22.6 \%$. On the concentration of the trade freedom, the coefficient implies that a one standard deviation improvement in trade freedom increases FDI by $18.4 \%$. Other different variables like government size, investment freedom, property rights, freedom from corruption, labor freedom, financial freedom, fiscal freedom and monetary freedom the coefficient implies that a one standard deviation improvement in size, investment freedom, property rights, freedom from corruption, labor freedom, financial freedom, fiscal freedom and monetary freedom increases FDI by $17.2 \%, 19.1 \%, 18.5 \%$, $18.4 \%, 6.4 \%, 7.9 \%, 7.3 \%$ and $11.3 \%$ respectively.

From the second column of the table: 11 the paper present the random effect estimates. In the case of institutional quality all the variables are positive and significant impact on FDI. In the case of political stability, regulatory quality, rules of law and control of corruption the coefficient implies that a one standard deviation improvement in political stability, regulatory quality, rules of law and control of corruption increases FDI by $24.7 \%, 19.3 \%, 17.4 \%$ and $35.3 \%$ which is slightly higher from than in the case of OLS and the other variable noted as government effectiveness the coefficient value is slightly lower from the OLS. The impact of all the variables under the economic freedom is also found positive and significant. In the case of business freedom the coefficient implies that a one standard deviation improvement in business freedom increases FDI by $29.4 \%$ which is slightly higher from than in the case of OLS. On the other hand in the case of the trade freedom, the coefficient implies that a one standard deviation improvement in trade freedom increased FDI by $15.8 \%$. Other different variables like government size, investment freedom, property rights, financial freedom, fiscal freedom and monetary freedom the coefficient implies that a one standard deviation improvement in government size, investment freedom, property rights, financial freedom, fiscal freedom and monetary freedom increases FDI by 15.4\%, 7.5\%, 16.4\%, 6.3\%, 7.1\% and $8.9 \%$ which is slightly lower from than in the case of OLS. On the other hand freedom from corruption and labor freedom, the coefficient implies that a one standard deviation improvement in freedom from corruption and labor freedom increases FDI by $27.4 \%$ and $7.5 \%$ which is slightly higher from than in the case of OLS.

The third column which represents fixed effect model .Under the fixed effect model in the case of political stability, regulatory quality, rules of law and control of corruption the coefficient implies that a one standard deviation improvement in political stability, government effectiveness, regulatory quality, rules of law and control of corruption increases FDI by $19.2 \%, 29.3 \%, 23.6 \%, 21.5 \%$ and $45.2 \%$ which is slightly higher from than in the case of OLS. According to the fixed effect estimates here are also the impact of all the 
variables under the economic freedom is also explored to be positive and significant. In the case of business freedom, trade freedom, government size, investment freedom, property rights, freedom from corruption, labor freedom, financial freedom, fiscal freedom and monetary freedom the coefficient implies that a one standard deviation improvement in business freedom, trade freedom, government size, investment freedom, property rights, freedom from corruption, labor freedom, financial freedom, fiscal freedom and monetary freedom increases FDI by 35.8\%, 19.2\%, 29.5\%, 29.4\%, 25.3\%,30.7\%, 27.3\%,19.2\%,29.3\% and $21.0 \%$ respectively which is higher from than in the case of OLS and Random Effect Model.

The fourth column presented the Poisson Regression estimates. Under the institutional quality all the variables are positive and significant influence on FDI. The coefficient implies that a one standard deviation improvement in political stability, government effectiveness, regulatory quality, rules of law and control of corruption increased FDI by $15.9 \%, 34.8 \%$, $29.5 \%, 20.8 \%$ and $42.4 \%$. In the case of business freedom, trade freedom, government size, financial freedom and monetary freedom the coefficient implies that a one standard deviation improvement in business freedom, trade freedom, government size, financial freedom and monetary freedom increases FDI by $36.3 \%, 24.7 \%, 31.3 \%, 25.1 \%$ and $27.3 \%$ respectively which is slightly higher than in the case of OLS, Random Effect Model and Fixed Effect Model. On the other hand the other variables like investment freedom, property rights, freedom from corruption, labor freedom and fiscal freedom the coefficient implies that a one standard deviation improvement in investment freedom, property rights, freedom from corruption, labor freedom and fiscal freedom increases FDI by 15.7\%, 19.4\%, 29.5\%, 23.6\% and $27.3 \%$ respectively and which is slightly lower from the fixed effect model.

Table 11. Panel regression

\begin{tabular}{|c|c|c|c|c|c|c|c|}
\hline Estimation & 1 & 2 & 3 & 4 & 5 & 6 & 7 \\
\hline Method & OLS & $\begin{array}{l}\text { Random } \\
\text { Effect }\end{array}$ & Fixed effect & $\begin{array}{l}\text { Poisson } \\
\text { Regression }\end{array}$ & $\begin{array}{l}\text { Prais-Winst } \\
\text { en }\end{array}$ & GMM & GEE \\
\hline \multicolumn{8}{|l|}{$\begin{array}{l}\text { Log } \\
\text { Dependent } \\
\text { Variables }\end{array}$} \\
\hline $\begin{array}{l}\text { Political } \\
\text { Stability and } \\
\text { absence of } \\
\text { violence }\end{array}$ & $\begin{array}{l}0.187 \\
(2.129)^{* * *}\end{array}$ & $\begin{array}{l}0.247 \\
(1.241)^{* * *}\end{array}$ & $\begin{array}{l}0.192 \\
(2.684)^{* * *}\end{array}$ & $\begin{array}{l}0.159 \\
(2.431)^{* * *}\end{array}$ & $\begin{array}{l}0.229 \\
(1.195)^{* * *}\end{array}$ & $\begin{array}{l}0.242 \\
(2.362)^{* * *}\end{array}$ & $\begin{array}{l}0.317 \\
(2.144)^{* * *}\end{array}$ \\
\hline $\begin{array}{l}\text { Government } \\
\text { Effectiveness }\end{array}$ & $\begin{array}{l}0.221 \\
(1.292)^{* *}\end{array}$ & $\begin{array}{l}0.203 \\
(1.484)^{* *}\end{array}$ & $\begin{array}{l}0.293 \\
(2.355)^{* * *}\end{array}$ & $\begin{array}{l}0.348 \\
(1.926)^{* * *}\end{array}$ & $\begin{array}{l}0.219 \\
(1.229)^{* * *}\end{array}$ & $\begin{array}{l}0.362 \\
(2.625)^{* * *}\end{array}$ & $\begin{array}{l}0.316 \\
(3.418)^{* * *}\end{array}$ \\
\hline $\begin{array}{l}\text { Regulatory } \\
\text { quality }\end{array}$ & 0.143 & 0.193 & 0.236 & 0.295 & 0.244 & 0.285 & 0.324 \\
\hline
\end{tabular}




\section{Macrothink}

International Journal of Accounting and Financial Reporting ISSN 2162-3082 2018, Vol. 8, No. 4

\begin{tabular}{|c|c|c|c|c|c|c|c|}
\hline & $(1.652)^{* *}$ & $(2.428) * *$ & $(1.903) * *$ & $(2.844)^{* *}$ & $(2.916) * *$ & $(2.726) * *$ & $(3.832)^{* *}$ \\
\hline & 0.148 & 0.174 & 0.215 & 0.208 & 0.226 & 0.263 & 0.285 \\
\hline Rules of Law & $(1.437)^{* *}$ & $(2.518)^{* *}$ & $(1.258)^{* *}$ & $(2.705)^{* *}$ & $(2.065)^{* *}$ & $(2.843)^{* *}$ & $(4.647)^{* *}$ \\
\hline Control of & 0.214 & 0.353 & 0.452 & 0.424 & 0.366 & 0.576 & 0.584 \\
\hline Corruption & $(1.563)^{* *}$ & $(1.763)^{* *}$ & $(2.326)^{* *}$ & $(2.572)^{* *}$ & $(2.853)^{* *}$ & $(2.965)^{* *}$ & $(3.225)^{* *}$ \\
\hline Business & 0.226 & 0.290 & 0.358 & 0.363 & 0.349 & 0.295 & 0.318 \\
\hline Freedom & $(1.548)^{* *}$ & $(1.826)^{* *}$ & $(2.441)^{* *}$ & $(2.195)^{* *}$ & $(2.948)^{* *}$ & $(2.784)^{* *}$ & $(2.185)^{* *}$ \\
\hline Trade & 0.184 & 0.158 & 0.192 & 0.247 & 0.283 & 0.316 & 0.382 \\
\hline Freedom & $(1.418)^{* *}$ & $(1.161)^{* *}$ & $(1.372)^{* *}$ & $(1.804)^{* *}$ & $(1.972)^{* *}$ & $(2.166)^{* *}$ & $(2.870)^{* *}$ \\
\hline Government & 0.172 & 0.154 & 0.295 & 0.313 & 0.337 & 0.398 & 0.417 \\
\hline Size & $(1.283)^{* *}$ & $(1.317)^{* *}$ & $(2.392)^{* *}$ & $(2.573)^{* *}$ & $(2.793)^{* *}$ & $(3.741)^{* *}$ & $(3.894)^{* *}$ \\
\hline Investment & 0.191 & 0.175 & 0.294 & 0.157 & 0.215 & 0.314 & 0.392 \\
\hline Freedom & $(0.862)^{* *}$ & $(0.531)^{* *}$ & $(2.653)^{* *}$ & $(1.459)^{* *}$ & $(1.941)^{* *}$ & $(2.964) * *$ & $(3.288)^{* *}$ \\
\hline Property & 0.185 & 0.164 & 0.253 & 0.194 & 0.238 & 0.296 & 0.317 \\
\hline Rights & $(1.091)^{* *}$ & $(1.120)$ & $(2.465)^{* *}$ & $(1.672)^{* *}$ & $(1.859)^{* *}$ & $(2.152)^{* *}$ & $(2.859)^{* *}$ \\
\hline Freedom & 0.184 & 0.274 & 0.307 & 0.295 & 0.305 & 0.272 & 0.462 \\
\hline $\begin{array}{l}\text { From } \\
\text { Corruption }\end{array}$ & $(1.063)^{* *}$ & $(1.114)^{* *}$ & $(2.351)^{* *}$ & $(2.151)^{* *}$ & $(2.316)^{* *}$ & $(2.346)^{* *}$ & $(3.463)^{* *}$ \\
\hline Labor & 0.064 & 0.075 & 0.273 & 0.236 & 0.219 & 0.284 & 0.325 \\
\hline Freedom & $(0.593)^{* *}$ & $(0.715)^{* *}$ & $(2.127)^{* *}$ & $(2.194)^{* *}$ & $(2.128)^{* *}$ & $(2.393)^{* *}$ & $(3.102)^{* *}$ \\
\hline Financial & 0.079 & 0.063 & 0.192 & 0.251 & 0.326 & 0.263 & 0.352 \\
\hline Freedom & $(0.624)^{* *}$ & $(0.439)$ & $(1.260)^{* *}$ & $(2.014)^{* *}$ & $(2.962)^{* *}$ & $(2.273)^{* *}$ & $(4.293)^{* *}$ \\
\hline Fiscal & 0.073 & 0.071 & 0.293 & 0.252 & 0.284 & 0.317 & 0.414 \\
\hline Freedom & $(0.529)^{* *}$ & $(0.458)^{* *}$ & $(1.157)^{* *}$ & $(2.117)^{* *}$ & $(2.021)^{* *}$ & $(3.157)^{* *}$ & $(4.571)^{* *}$ \\
\hline Monetary & 0.113 & 0.089 & 0.210 & 0.273 & 0.216 & 0.294 & 0.316 \\
\hline \multirow[t]{2}{*}{ Freedom } & $(0.815)^{* *}$ & $(0.742)^{* *}$ & $(1.528)^{* *}$ & $(2.417)^{* *}$ & $(2.146)^{* *}$ & $(0.283)^{* *}$ & $(0.337)^{* *}$ \\
\hline & 0.096 & 0.073 & 0.105 & 0.604 & 0.917 & 0.806 & 0.688 \\
\hline DEMOC & $(0.642)^{* *}$ & $(0.592)^{* *}$ & $(0.448)^{* *}$ & $(0.758)^{* *}$ & $(0.836)^{* *}$ & $(1.038)^{* *}$ & $(1.295)^{* *}$ \\
\hline
\end{tabular}

Source: Own Calculation 


\section{Mll Macrothink}

International Journal of Accounting and Financial Reporting

ISSN 2162-3082

2018, Vol. 8, No. 4

From the fifth column according to the Prais-Winsten estimates, here all the variables under the institutional qualities are positive and significant. Here the coefficient of the political stability and rules of law are slightly higher from the poisson regression estimates. On the other hand the coefficient of government effectiveness, regulatory qualities and control of corruption implies that a one standard deviation improvement in government effectiveness, regulatory qualities and control of corruption increases FDI by $21.9 \%, 24.4 \%$ and $36.6 \%$ respectively which are slightly lower from the poisson regression estimates. In the case of business freedom, labor Freedom, and monetary freedom the coefficient implies that a one standard deviation improvement in business freedom, labor freedom and monetary freedom increases FDI by 34.9\%, 21.9\% and $21.6 \%$ respectively which is lower from the poisson regression estimates. On the other hand the other variables under the economic freedom like trade freedom, government sizes, investment freedom, property rights, freedom from corruption, financial freedom and fiscal freedom the coefficient implies that a one standard deviation improvement in trade freedom, government sizes, investment freedom, property rights, freedom from corruption, financial freedom and fiscal freedom increases FDI by $28.3 \%, 33.7 \%, 21.5 \%, 23.8 \%, 30.5 \%, 32.6 \%$ and $28.4 \%$ respectively which is slightly lower from the poisson regression estimates.

From the sixth column of the table concentrates on the GMM estimates, here noted that all the variables under the institutional qualities are positive and significant. The coefficient values of the political stability, government effectiveness, regulatory qualities, rules of law and control of corruption implies that a one standard deviation improvement in political stability, government effectiveness, regulatory qualities, rules of law and control of corruption increases FDI by $24.2 \%, 36.2 \%, 28.5 \%, 26.3 \%$ and $57.6 \%$ respectively. On the other hand the economic freedoms are also explored to be positive and significant. In the case of business freedom, trade freedom, government Size, investment freedom, property rights, freedom from corruption, labor freedom, financial freedom, fiscal freedom and monetary freedom the coefficient implies that a one standard deviation improvement in business freedom, trade freedom, government size, investment freedom, property rights, freedom from corruption, labor freedom, financial freedom, fiscal freedom and monetary freedom increases FDI by $29.5 \%, 31.6 \%, 39.8 \%, 31.4 \%, 29.6 \%, 27.2 \%, 28.4 \%, 26.3 \%, 31.7 \%$ and $29.4 \%$ respectively.

From the seven column of the table according to the GEE estimates, all the variables under the institutional quality and economic freedom are also explored to be positive and significant. The coefficient values of the political stability, government effectiveness, regulatory qualities, rules of law and control of corruption implies that a one standard deviation improvement in political stability, government effectiveness, regulatory qualities, rules of law and control of corruption increases FDI by $31.7 \%, 31.6 \%, 32.4 \%, 28.5 \%$ and $58.4 \%$ respectively. In the case of business freedom, trade freedom, government size, investment freedom, property rights, freedom from corruption, labor freedom, financial freedom, fiscal freedom and monetary freedom the coefficient implies that a one standard deviation improvement in business freedom, trade freedom, government Size, investment freedom, property rights, freedom from corruption, labor freedom, financial freedom, fiscal freedom and monetary 
freedom increases FDI by 31.8\%, 38.2\%, 41.7\%, 39.2\%, 31.7\%, 46.2\%, 32.5\%, 35.2\%, 41.4\% and $31.6 \%$ respectively.

\section{Conclusion}

In the light of the results obtained from this study, it can be concluded that institutional quality and economic freedom encourages the FDI in the developing countries. It is true that government should ensure to achieve a sound degree of political and economic stability, along with a market-oriented environment that really assists for proliferating economic growth in the developing countries. It is important that alleviate government intervention and escalate the economic freedom that accelerates the business productivity and profitability along with the formulating sustainable environment where the firms are integrated and interrelated with the world market for encouraging uninterrupted innovation and competition.

\section{References}

Alfaro, L., Chanda, A., Kalemli-Ozcan, S., \& Sayek, S. (2004). FDI and Economic Growth: The Role of Local Financial Market. Journal of International Economics, 64, 113-34.

Ali, F. A., Fless, N., \& MacDonald, R. (2010). Do Institutions Matter for Foreign Direct Investment?. Open Economies Review, 21, 201-219.

Asiedu, E. (2006). Foreign direct investment in Africa: the role of government policy, institutions and political instability. World Economy, 29(1), 63-77.

Aysan, A. F., Pang, G., Ange, M., \& Varoudakis, V. (2006). Uncertainty, Economic Reforms and Private Investment in the Middle East and North Africa. The Applied Economics.

Azman-Saini,W. N., Baharumshah, A. Z., \& Law, S. H. (2010). Foreign direct investment, economic freedom and economic growth: International Evidence. Economic Modelling, 27(5), 1079-89.

Barro, R. J. (1997). Determinants of economic growth: a cross country empirical study. Cambridge: The MIT Press.

Bénassy-Quéré, A., Coupet, M., \& Mayer, T. (2007). Institutional Determinants of Foreign Direct Investment. The World Economy, 30(5), 764-782.

Bengoa, M., \& Robles, S. (2003). FDI, economic freedom, and growth: New evidence from Latin America. European Journal of Political Economy, 19, 529-545.

Busse, M., \& Groizard, J. (2008). Foreign direct investment, regulations and growth. The World Economy, 31(7), 861-886.

Busse, M., \& Hefeker, C. (2005). Political Risk, Institutions and Foreign Direct Investment. HWWA Discussion Paper.

Busse, M., \& Hefeker, C. (2007). Political Risk, Institutions and Foreign Direct Investment. European journal of Political Economy, 23, 397-415. 


\section{MInstitute Macrothink $_{\text {Int }}$}

International Journal of Accounting and Financial Reporting

ISSN 2162-3082

Chakrabarti, A. (2001). The Determinants of Foreign Direct Investment: Sensitivity Analysis of Cross-Country Regressions. Kyklos, 54(1), 89-113.

Compton, R. A., Giedeman, D. C., \& Hoover, G. A. (2011). Panel evidence on economic freedom and growth in the United States. European Journal of Political Economy, 27, 423-435.

Daude, C., \& Stein, E. (2007). The Quality of Institutions and Foreign Direct Investment. Economics and Politics, 19(3), 317-344.

Dawson, J. W. (1998). Institutions, investment, and growth: new cross-country and panel data evidence. Economic Inquiry, 36(4), 603-620.

De Hann, J., Lundstrom, S., \& Sturm, J. (2006). Market-oriented institutions and policies and economic growth: A Critical Survey. Journal of Economic Surveys, 20, 157-91.

Durham, J. B. (2004). Absorptive capacity and the effects of foreign direct investment and equity foreign portfolio investment on economic growth. European Economic Review, 48, 285-306.

Dutta, N., \& Osei-Yeboah, K. (2010). Foreign Direct Investment and Human Capital: The Role of Political and Civil Rights. Journal of International Development. Retrieved from http://ssrn.com/abstract=1263038

Estrin, S., Bevan, A., \& Meyer, K. (2001). Institution building and the integration of Eastern Europe in international production. Working Paper 16/01, Centre for New \& Emerging Markets.

Ghura, D., \& Goodwin, B. (2000). Determinants of private investment: A cross-regional empirical investigation. Applied Economics, 32(14), 1819-1835.

Gwartney, J. (2009). Institutions, economic Freedom and cross-country differences in performance. Southern Economic Journal, 75(4), 937-956.

Habib, M., \& Zurawicki, L. (2002). Corruption and Foreign Direct Investment. Journal of International Business Studies, 33(2), 291-307.

Hausmann, R., \& FernándezArias, E. (2000). Foreign Direct Investment: Good Cholesterol?. Inter-American Development Bank Working Papers 407. New Orleans, United States: Inter-American Development Bank.

Heckelman, J. C. (2000). Economic freedom and economic growth: a short-run causal investigation. Journal of Applied Economics, 3(1), 71-91.

Henisz, W. J. (2000). The institutional environment for multinational investment. Journal of Law, Economics and Organization, 16(2), 334-364.

Huang, Y. (2003). Selling China: Foreign investment during the reform era. New York: Cambridge University Press. 
Jude, C., \& Leveieuge, G. (2013). Growth effect of FDI in developing economies: The role of institutional quality. MPRA Paper. Retrieved January 26, 2016, from https://mpra.ub.uni-muenchen.de/49321/

Kaufmann, D., Kraay, A., \& Mastruzzi, M. (2007). Worldwide Governance Indicators Project: Answering the Critics'. World Bank, Policy Research Working Paper No. 4149, Washington. Retrieved from http://papers.ssrn.com/sol3/papers.cfm?abstract id=965077

Kok, R., \& Ersoy, A. B. (2009). Analyses of FDI determinants in developing countries. International Journal of Social Economics, 36(1/2), 105-123.

Li, S. (2005). Why a poor governance environment does not deter foreign direct investment: The case of China and its implication for investment protection. Business Horizon, 48, 297-302.

Li, S., \& Filer, L. (2004, July 10-13). Governance environment and mode of investment. The Academy of International Business Annual Meeting, Stockholm, Sweden.

Li, X., \& Liu, X. (2005). Foreign Direct Investment and Economic Growth: An Increasingly Endogenous Relationship. World Development, 33(3), 393-407.

Marta, B., \& Sanchez-Robles, B. (2003). Foreign direct investment, economic freedom and growth: new evidence from Latin America. European Journal of Political Economy, 19, 529-545.

Mlambo, K. (2006). Reviving Foreign Direct Investments in Southern Africa: Constraints and Policies. African Development Review, 17(3), 552-579.

Moskalev, S. (2007). Governance and foreign direct investment. Mimeo, Adelphi University, School of Business.

Nasir, Z. M., \& Hassan, A. (2011). Economic Freedom, Exchange Rates Stability and FDI in South Asia.The Pakistan Development Review, 50(4), 423-433.

Noorbaskhsh, F., Paloni, A., \& Youssef, A. (2001). Human Capital and FDI Inflows to Developing Countries: New Empirical Evidence. World Development, 29(9), 1593-1610.

Onyeiwu, S., \& Shrestha, H. (2004). Determinants of foreign direct investment in Africa. Journal of Developing Societies, 20, 89-106.

Rodrik, D, Subramanian, A., \& Trebbi, F. (2002). Institutions Rule: The Primacy of Institutions over Geography and Integration in Economic Development. NBER Working Paper No. 9305.

Saadatmand, Y., \& Choquette, J. (2012). Neo-Liberal Policy and Foreign Direct Investment in Africa. International Journal of Business and Social Science, 3(17).

Wernick, D., Haar, J., \& Singh, S. (2009). Do Governing Institutions Affect Foreign Direct Investment? New Evidence from Emerging Economies. International Journal of Economics and Business Research, 1(3), 317-332. 


\section{Macrothink}

International Journal of Accounting and Financial Reporting ISSN 2162-3082 2018, Vol. 8, No. 4

Yeyati, E., Panizza, U., \& Stein, E. (2007). The cyclical nature of North-South FDI Flows. Journal of International Money and Finance, 26, 104-130.

Zhang, H. K. (2008). What attracts Foreign Multinational Corporations to china?. Contemporary Economic Policy, 19(3), 336-34.

Zhu, B. (2007, April 27). Fortune or Evil? The Effects of Inward Foreign Direct Investment on Corruption. The Mini-APSA Conference at the Department of Political Science, Columbia University.

\section{Copyright Disclaimer}

Copyright for this article is retained by the author(s), with first publication rights granted to the journal.

This is an open-access article distributed under the terms and conditions of the Creative Commons Attribution license (http://creativecommons.org/licenses/by/4.0/) 